\title{
DÜNYA TİCARET ÖRGÜTÜ KAMU ALIMLARI ANLAŞMASINA GENEL BİR BAKIŞ VE BU ANLAŞMANIN AVRUPA BİRLIĞİ'NDE UYGULANMASI
}

\author{
Servet ALYANAK*
}

\section{$\ddot{O}_{z}$}

Dünya Ticaret Örgütü (DTÖ) Kamu Alımlarl Anlaşması (KAA) dünya ticaretinin serbestleştirilmesine katkı yapmayı ve kamu ihale piyasasinı uluslararası ticaret kurallarının kapsamı altına almayı amaçlamaktadır. Şu anda 42 ülke bu Anlaşmaya taraf olmuştur. Anlaşma bir kamu ihalesine katılan işletmeleri doğrudan muhatap alan çeşitli düzenlemeler içermesi itibariyle yeni bir çı̆̆ır açmıştır. Anlaşma, kendi kapsamına giren ihalelerde, taraf ülkelerin ve tedarikçilerinin yararına olacak şekilde ayırımcılık yapılması yasağı, ulusal muamele, en çok kayırılan ülke ve şeffaflık prensiplerini temel almaktadır. Acaba bu işletmeler KAA'nın ilgili hükümlerini gerekçe göstererek Avrupa Birliği (AB) hukuku bağlamında bu hükümlerin uygulanmasını talep edebilirler mi? Ya da bu işletmeler KAA'dan kaynaklanan haklarını ancak $A B$ yasa koyucusunun kendi iç hukukunu (AB hukukunu) KAA'ya uyumlaştırdiğ oranda ve bu Anlaşma kapsamında kalan yabancı işletmelere Anlaşmada uygulanması öngörülen usuller doğrultusunda mı ileri sürebilecektir? Bu makale okuyucuya KAA hakkında genel bir bakış sağlamakta ve KAA'nın temel niteliklerini gözden geçirmektedir. Bunun yanı sıra makale, KAA'nın bazı hükümlerinin AB Üye Devletlerinin ulusal mahkemelerinde uygulanmasını ileri sürme sorununu da tartışmaktadır. Makalenin ilk kısmı DTÖ KAA'y yluslararası kamu ihale mevzuatı bağlamında analiz etmekte ve bu açıdan önemli noktalara değinmektedir. İkinci kısım, KAA'nın hukuki niteliğ $i$ ve temel özelliklerini incelemektedir.

Anahtar kelimeler: Dünya Ticaret Örgütü, Kamu Alımları Anlaşması, kamu ihaleleri, ayırımcılık yapma yasağı, şeffaflık, ticaretin serbestleştirilmesi.

* Dr. (LL.M, Mag. Iur., Ph.D), Hâkim, Kamu Denetçiliği Kurumu, e-posta: servet.alyanak@ombudsman.gov.tr 


\section{GENERAL OVERVIEW OF THE GOVERNMENT PROCUREMENT AGREEMENT OF THE WORLD TRADE ORGANIZATION AND IMPLEMENTATION OF THIS AGREEMENT IN THE EUROPEAN UNION}

\section{Abstract}

The World Trade Organization Government Procurement Agreement (GPA) aims to contribute to the liberalization of world trade and to bring government procurement under international trade rules. Currently, 42 countries are parties to the agreement. The GPA is breaking a new ground in that it contains numerous clauses which appear to directly address undertakings involved in a procurement procedure. It contains obligations of non-discrimination, national treatment, mostfavored-nation treatment and transparency principles for procurement of goods and services by related government entities of its signatories. The GPA is based on the principles of openness, transparency and non-discrimination, which apply to Parties' procurement covered by the Agreement, to the benefit of Parties and their suppliers. But can these undertakings rely on related GPA provisions under the European Union (EU) law? Or are their benefits acquired from the GPA limited to the extent that the EU has decided to align its own internal law (EU law) with the procedures that it must apply towards certain external contractors under the GPA? This paper provides the reader with a general overview of the GPA and gives an overview of the main characteristics of the GPA. In addition, it discusses the question whether suitable GPA provisions can be invoked in the national courts of EU Member States. Section one highlights and analyses the WTO GPA within the context of international public procurement legislation. Section two examines the main features of the GPA and its legal nature.

Keywords: World Trade Organization, Government Procurement Agreement, public contracts, non-discrimination, transparency, liberalization of trade.

\section{Giriş}

Neden bazı devletler kamu ihale piyasalarını yabancı katılımcılara açık tutmayı kabul etmekte iken diğer devletler bunu kabul etmemektedir? Bu tercih ülkelerin ekonomik yapısı ile izah edilebilirse de liberal bir ekonomik yapıya sahip bir kısım ülkelerin dahi bu konuda korumacı bir yaklaşım geliştirdikleri de bir gerçektir. Bu konuya çalışmanın ilerleyen bölümlerinde değinilecektir. Tabiatıyla bu yönde kamu ihale piyasalarını şeffaf ve dış rekabete yani yabancı kişi ve isteklilere açmak gibi bir eğilim içerisinde olmak isteyen ülkelerin platformunun da neresi olması konusu bu açıdan önem arz eder. 
Günümüze kadar sadece kamu ihalesi konusuna odaklanması ve DTÖ anlaşmaları içerisinde taraf olan ülkeler açısından yasal anlamda bağlayıcı niteliğe sahip olması nedeniyle DTÖ Kamu Alımları Anlaşması bu alandaki tek uluslararası anlaşmadır. Gerek bölgesel (AB, NAFTA vb.) gerekse diğer uluslararası kuruluşların (UNCITRAL Birleşmiş Milletler Ticaret Hukuku Komisyonun Model Kanunu, OECD -Ekonomik İşbirliği ve Gelişme Teşkilatı- ve Dünya Bankası'nın) kamu ihalesi alanındaki düzenlemeleri ise aşağıda inceleneceği üzere bu nitelikte değildir.

Bu çalışmanın amacı, AB'nin de Kamu Alımları Anlaşması'na (KAA'ya) taraf olması nedeniyle AB hukukunun da bir parçası olan KAA'nın genel gereklilikleri ve prensipleri hakkında bilgi vererek okuyucuya KAA'nın bilimsel açıdan analizini yapmaktır. İlk önce KAA'nın DTÖ Anlaşmaları çerçevesindeki yerini anlamak için DTÖ’nün genel yapısı ve özellikleri hakkında bazı bilgiler verilmiştir. Tarihsel açıdan bazı gelişmelere ilişkin bilgi verildikten sonra KAA'nın sistemi ve genel prensipleri üzerinde inceleme yapılmıştır.

\section{Uluslararası kamu ihale mevzuatı ve DTÖ Kamu Alımları Anlaşması}

\subsection{Kamu İhalesi İle İlgili Uluslararası Düzenlemeler}

DTÖ küresel anlamda malların ve hizmetlerin ticaretinin akışını kolaylaştırmayı amaçlamaktadır. DTÖ bağlamında 'ekonomik küreselleşme', küresel mal ve hizmet ticaretini entegre etme süreci ve sınırların doğrudan yabanc1 yatırıma açılması olarak tanımlanmıştır. ${ }^{1}$

DTÖ’nün diğer işlevlerinin yanı sıra bu konuda gerekli platformu sunan bir uluslararası örgüttür. DTÖ kuralları, devletlerarasındaki uluslararası ticaretle ilgili iken DTÖ kamu ihale kuralları, bir tedarikçinin yabancı bir Devletteki kamu ihalesine katılımını kolaylaştııır, ama aynı zamanda da yolsuzluğu ortadan kaldırmak için kamu alımı sürecinde şeffaflık da temin eder. Kamu ihaleleri, kamu alımı piyasasının dikkate değer büyüklüğü (çoğunlukla GSYH’nin yüzde $10-15$ 'i) ve artan rekabet açısından yerel ve yabancı firma ve kişilere yararı dikkate alındığında uluslararası ticaretin önemli bir yönüdür. Birçok DTÖ üyesi, satın alma kararlarını belli yerel endüstri sektörlerinin veya sosyal grupların desteklenmesi gibi ulusal politika hedeflerini elde etmek için kullanır. Açık, şeffaf ve ayırım gözetmeyen bir kamu ihalesi rejimi, tedarikçiler arasındaki rekabeti optimize etmesi nedeniyle genellikle, 'paranın değerinin karşılığının alınması' ve 'verimlilik' açısından en iyi araç olarak kabul edilir.

1 Dünya Ticaret Örgütü, World Trade Report 2008: Trade in a Globalising World, s.15, http://www.wto.org/english/res_e/booksp_e/anrep_e/world_trade_report08_e.pdf, Erişim: 18 Kasım 2013. 
DTÖ hukuku kurallarının, ülke-içi ticari muamelelere yönelik olmayıp sadece sınır ötesi (sınırlararası) işlemlerde uygulanması durumu vardır. Ayrıca, DTÖ üyesi bir devletin, bir başka DTÖ üyesi devletten mal veya hizmet ithaline ticari engeller koyduğu durumlarda geçerlidir. Örneğin, AB'deki bir kamu idaresinin gerçekleştireceği bir kamu ihalesinde, DTÖ KAA kuralları, Japonya'daki bir isteklinin ayrımcı olmayan bir biçimde muamele görmesini sağlar. DTÖ KAA kuralları sadece ülke-içi etkileri olan durumlarda geçerli değildir. Örneğin, Japonya, kendi iç üretimini ilgilendiren ve benzer ürünlerin ithali üzerinde etkisi olmayan bazı kısıtlamalar koyarsa o zaman DTÖ kuralları sadece ülke-içi etkileri olan ve sınır ötesi ticari etkisi olmayan bu tedbirlere uygulanmayacaktır.

Kamu ihale süreçlerinin yeknesak veya paralel bir akış içerisinde gerçekleştirilmesine yönelik çalışmalar son yıllarda uluslararası boyutta dikkat çekmiştir. Ancak, gerek Birleşmiş Milletler'in (BM) "Yolsuzluğa Karşı Birleşmiş Milletler Sözleşmesi” gerekse OECD'nin (Ekonomik İşbirliği ve Gelişme Teşkilatı'nın) bünyesinde hazırlanan "Uluslararası Ticari İslemlerde Yabancı Kamu Görevlilerine Rüşvet Verilmesinin Önlenmesi Sözleşmesi” gibi tasarruflar, diğer konuların yanı sıra, kamu ihalesi konusunu ele almakla beraber uluslararası örgütlerin bu çalışmaları doğrudan kamu ihalesi piyasasının serbestleştirilmesini ele alan düzenlemeler değildir. ${ }^{2}$ Dünya Bankası, Dünya Bankası tarafından finanse edilen projelere uygulanması amacıyla bir kamu alım kılavuzunu çıkarmıştır. Dünya Bankası, bu tür projelerin, politik veya başka ekonomik olmayan düşünce ve saiklere göre belirlenmesini önlemek amacıyla bağlayıcı olmayan Kamu Alımları Kılavuzunu kabul etmiştir.

Birleşmiş Milletler Ticaret Hukuku Komisyonun (UNCITRAL) Kamu Alımları Model Kanunu ${ }^{3}$ ise, ülkeler açısından model bir kanun olmak dışında bağlayıcı bir niteliği yoktur. UNCITRAL Model Kanunu, bağlayıcı bir yasal enstrüman değildir, daha çok ulusal hükümetlerin kamu ihale mevzuatı değişiklikleri uygularken kullanmaları için bir araçtır. UNCITRAL Model Kanunu, ihale sürecinde bütünlük, güven, adalet ve şeffaflık sağlayarak ihalede verimlilik ve rekabeti desteklemek için tasarlanan usuller oluşturmak ve böylece gelişmiş bir ekonomik kalkınmaya yol açmayı hedeflemiştir. UNCITRAL Model Kanunu, bazı ülkeler tarafından kamu alımıyla ilgili ulusal mevzuatı değiştirme konusunda esin kaynağı olarak

2 R. D.Anderson andW. E.Kovacic, (2009), "Competition policy and international trade liberalisation: essential complements to ensure good performance in public procurement markets", Public Procurement Law Review, 18(2), ss.67-101, s. 68.

31993 yılında UNCITRAL, Birleşmiş Milletler Uluslararası Ticaret Hukuku Komisyonu, Mal ve Yapım İşleri İhaleleri için Model Kanunu Komisyonun 26.genel toplantısında kabul etmiş, 1994 yılında yapılan 27. genel toplantısında da Mal, Hizmet Alımı ve Yapım İşleri İhaleleri için ayrı bir Model Kanunu daha kabul etmiş olup bu Model Kanun bir önceki Model Kanunun yerine geçmemiş her ikisi birlikte yürürlükte kalmıştır. Her iki Model Kanunun metinleri http://www.uncitral.org, Erişim: 10 Ocak 2014 web-sitesinde mevcuttur. 
uygulanmaktadır. Kamu alımlarına yönelik olarak farklı hukuki, sosyal ve ekonomik sistemlere sahip devletlerin kabul edebileceği model yasal hükümlerin oluşturulması uyumlu uluslararası ekonomik ilişkilerin geliştirilmesine katkıda bulunmayı amaçlamaktadır. Söz konusu Model Kanun da birkaç ülkenin kamu alımları sistemine adapte edilmiş olmakla birlikte yaygın bir uygulamaya henüz kavuşamamıştır. UNCITRAL Model Kanununun uluslararası örf ve adet hukuku statüsünde kabul edilirliği de mümkün gözükmemektedir. Zira UNCITRAL Model Kanununun bazı hükümlerinin bu statüde kabul edilebilmesi için çok daha geniş sayıdaki devletler açısından yaygın bir uygulamaya kavuşturulmuş olması gerekmektedir.

Gerek BM UNCITRAL Model Kanunu gerekse OECD'nin kamu ihalesi ile ilgili kuralları da kılavuz niteliğindedir. $\mathrm{Bu}$ açıdan, ilgili uluslararası düzenlemelerin, kamu ihalelerinde serbestleşmeyi destekleyici işlevi bulunmakla birlikte; DTÖ KAA, uluslararası kamu ihalesi piyasasının serbestleştirilmesini doğrudan hedeflemesi itibariyle önemli bir metindir. ${ }^{4}$ DTÖ KAA'nın aynı zamanda kamu alımlarına ilişkin hükümler içeren iki taraflı uluslararası anlaşmalar yönünden de bir model niteliği vardır. ${ }^{5}$ DTÖ Kamu Alımları Anlaşması, UNCITRAL Model Kanunu ve Dünya Bankası'nın kamu alımlarıyla ilgili kuralları kamu alımlarında şeffaflığı arttırmak gibi ortak hedefleri paylaşmakla birlikte, UNCITRAL Model Kanunu ve Dünya Bankası ile OECD'nin kamu ihalesi ile ilgili kılavuzlarının bağlayıcı olmadığını ve KAA ile çelişkili olduklarında KAA'nın geçerli olduğunu unutmamak önemlidir.

Uluslararası ölçekte, bölgesel düzeydeki anlaşmalarda da kamu alımları hakkında çeşitli kurallar vardır. Kuzey Amerika Serbest Ticaret Anlaşması (NAFTA) Kanada, Meksika ve ABD arasındaki devletlerarası ilişkide kamu alımıla ilgili belli kurallara sahiptir. Doğu ve Güney Afrika Ortak Pazarı (COMESA), maddi kamu ihale kurallarının ittihazı açısından zayıf ise de üyelerinin kamu alımları hakkında kendi aralarındaki bilgi akışını arttırmalarını gerektirmektedir. ${ }^{6}$ Bu açıdan bakıldığında bölgesel düzeyde kamu ihalesi alanında yapılan düzenlemeler açısından $\mathrm{AB}$ kamu ihalesi kuralları, hem $\mathrm{AB}$ üye devletleri arasında hem de özel kişiler (gerçek ve tüzel kişiler) ve $A B$ üyesi devletlerarasında haklar ve yükümlülükler oluşturan kurallar olması ve kamu ihalesi alanının bölgesel düzeyde düzenleme altına alınması açısından en iyi örnektir.

\footnotetext{
${ }^{4}$ R. D.Anderson, (2007), "Renewing The WTO Agreement On Government Procurement: Progress To Date And Ongoing Negotiations", Public Procurement Law Review, 4, ss. 255-273, s. 257.

5 J. H.Grier, (2006), "Recent Developments In International Trade Agreements Covering Government Procurement", Public Contract Law Journal, 35(3), ss. 385-407, s. 388.

${ }^{6}$ COMESA’yı Kuran Anlaşma md 141.
} 


\subsection{Avrupa Birliği ve Kamu Alımları Anlaşması}

AB'nin kamu ihalesi kuralları sadece $28 \mathrm{AB}$ üyesi devlet tarafindan uygulanmamaktadır. AB kamu ihale kuralları, DTÖ tarafından müzakere edilen KAA başlıklı uluslararası anlaşma sayesinde başka ülkelerde de geçerlidir.?

$\mathrm{AB}$, üye devletlerinden bağımsız olarak ve onların yanında Dünya Ticaret Örgütünün müstakil bir üyesidir. Dolayısıyla, $\mathrm{AB}$ de eylem ve düzenlemelerinde, DTÖ'nün hedef, ilke ve kurallarına uymak ve üyelik yükümlülüğünün gereklerini yerine getirmek durumundadır. Aslında DTÖ KAA AB nezdinde AB Komisyonunca müzakere edilmiş ve AB tarafindan onaylanarak 1 Ocak 1996 tarihinde yürürlüğe girmiştir. $\mathrm{AB}$ Komisyonu hem $\mathrm{AB}$ 'yi temsilen hem de $\mathrm{AB}$ üyesi devletleri temsilen müzakerelerde bulunmuştur. $\mathrm{Bu}$ nedenle bu Anlaşmayı aslında kimin ( $A B$ üye devletlerin mi yoksa $A B$ 'nin mi) $A B$ ve üye devletler açısından sonuçlandırdığı belli değildir.

DTÖ KAA, Avrupa Birliği Adalet Divanının (ABAD) ERTA kararına ${ }^{8}$ uygun olarak Topluluğun örtülü yetkisi kapsamında kabul edilmiştir. AB tarafindan KAA'nın kabulü gibi yetkisi dâhilinde kalan alanlarda üye ülkeler açısından konulan kurallarda eğer üye ülkelerce üçüncü ülkelerle yapılan anlaşmalarla değişiklik yapılırsa $\mathrm{AB}$ tarafından konulan kurallar bundan etkilenir. ${ }^{9}$ Örneğin $\mathrm{AB}$ üyesi bir ülke $\mathrm{AB}$ üyesi olmayan üçüncü bir devlet ile yaptığı bir anlaşmada bu ülke isteklileri lehine kendi kamu ihalelerine katılım ve tekliflerin değerlendirilmesi ile ihalenin karara bağlanması açısından $A B$ üyesi ülkelerin firmalarına nazaran daha avantajlı koşullar öngörürse böyle bir durum ortaya çıar.

Avrupa Birliği, DTÖ Kamu Alımları Anlaşmasını sadece Ortak Ticaret Politikasını düzenleyen eski Avrupa Toplulukları (AT) Antlaşmasının 133. maddesi (Avrupa Birliğinin İşleyişi Hakkında Antlaşmanın [ABİHA] 207. maddesi) bağlamında kabul etmemiştir. Zira DTÖ Kamu Alımları Anlaşması, kapsamında kalan bazı hizmet alım ihaleleri bağlamında kişilerin serbest dolaşımını da içeren düzenlemeler de ihtiva ettiğinden ve bu nitelikteki hizmet alımları açısından AB'nin münhasır yetkisinden söz edilemeyeceğinden KAA hükümleri bir bütün olarak hem $\mathrm{AB}$ hem de $\mathrm{AB}$ üyesi devletlerce birlikte kabul edilmiş bir karma anlaşma (mixed agreement) niteliğindedir.

\footnotetext{
${ }^{7}$ Bu ülkeler şunlardır; 28 üye devletten oluşan Avrupa Birliği, Kanada, Hong Kong (sadece bu bölge açısından Çin), İzlanda, İsrail, Japonya, Kore, Lihtenştayn, Hollanda'ya ait Aruba, Norveç, Singapur, İsviçre, Amerika Birleşik Devletleri, Ermenistan ve Tayvan.

${ }^{8}$ Case 22/70 Commission v Council (ERTA) [1971] E.C.R. 263.

9 ECJ, Case 104/81 Kupferberg [1982] ECR 3641, para. [22]; Case 21-24/72 International Fruit Company [1972] ECR 1219, para. [20]; Case 12/86 Demirel [1987], ECR 3719, para. [14]; Case C61/94 Commission v Germany [1996] ECR I-3989, para. [52].
} 
AB hukuku kurallarının sadece üye ülkeler açısından uygulama alanı varken DTÖ Kamu Alımları Anlaşması kurallarının ise AB üyesi devletler ile bu Anlaşmaya taraf olan DTÖ üyesi ülkeler açısından uygulama alanı vardır. AB üyesi devletler yönünden bu iki kurallar manzumesi arasında yükümlülük açısından bir sıralama yapılacak olursa $\mathrm{AB}$ hukuku kaynaklı yükümlülüklere uluslarararası anlaşmadan kaynaklanan yükümlülüklere nazaran öncelik vermek durumundadırlar. Buna göre, bir kamu ihalesi hem AB kamu ihalesi kuralları hem de DTÖ KAA kuralları kapsamında kalan bir ihale ise ihaleyi gerçekleştiren idarenin bu iki kurallar manzumesine de uygun hareket etme zorunluluğu vardır. Böyle bir durumda örneğin, Fransız idaresince yapılan bir ihalede Fransız idaresi, İspanyol istekliye AB kamu ihale kurallarını, Japon istekliye de DTÖ KAA kurallarına uygun şekilde işlem yapmak durumundadır. AB kamu ihale yönergelerinin (2014/24/EU sayılı yönerge ${ }^{10}$ ve 2014/25/EU sayılı yönerge ${ }^{11}$ ) kuralları AB kurumları için değil $\mathrm{AB}$ üyesi devletler açısından uygulanırken DTÖ KAA hükümleri ise hem $\mathrm{AB}$ üyesi devletler hem de $\mathrm{AB}$ Komisyonu ve $\mathrm{AB}$ Konseyi'nce gerçekleştirilen kamu ihalelerine de tatbik edilir. Bununla birlikte aşağıda daha detaylı aktarılacağı üzere kapsam yönünden $\mathrm{AB}$ kamu ihale yönergeleri ile DTÖ KAA arasındaki farklılık çok fazla değildir.

AB kurumlarının satın alma faaliyetleri yönünden de 2002 yılında kabul edilen yeni Mali Tüzük ${ }^{12}$ uyarınca kabul edilen Mali Tüzük Uygulama Tüzüğünün ${ }^{13}$ giriş kısmının 25. paragrafında belirtildiği üzere $A B$ kamu ihale yönergelerindeki düzenlemeler esas alınarak bir takım kurallar konulmuştur. $\mathrm{AB}$ kurumları kamu ihale yönergelerinde öngörülen eşik değerlerin altında kalan ihalelerde bile yönergelerde öngörülen benzer ihale usullerine göre alım yapmak durumundadirlar.

Kamu Alımları Anlaşması, Dünya Ticaret Örgütü çerçevesi içerisinde kamu ihalelerinin düzenleme altına alındığ 1 yegâne dokümandır. KAA kamu ihaleleri alanında daha fazla serbestleşmeye ulaşılması düşüncesiyle maddî ve usulî

\footnotetext{
${ }^{10}$ Directive 2014/24/EU of the European Parliament and of the Council of 26 February 2014 on public procurement and repealing Directive 2004/18/EC (Üye devletlerdeki kamu mal, yapım ve hizmet alımı ihalelerinin karara bağlanması prosedürlerine ilişkin yönerge), OJ L/94/65, 28.3.2014.

${ }^{11}$ Directive 2014/25/EU of the European Parliament and of the Council of 26 February 2014 on procurement by entities operating in the water, energy, transport and postal services sectors and repealing Directive 2004/17/EC (Üye devletlerdeki su, enerji, ulaştırma ve posta sektörlerinde faaliyet gösteren kuruluşların alım usullerinin koordinasyonuna ilişkin yönerge), OJ L 94/243, 28.3.2014.

${ }^{12}$ Council Regulation (EC, Euratom) No 1605/2002 of 25 June 2002 on the Financial Regulation applicable to the general budget of the European Communities (Official Journal of the European Communities L 248, 16.09.2002).

13 Commission Regulation (EC, Euratom) No 2342/2002 of 23 December 2002 laying down detailed rules for the implementation of Council Regulation (EC, Euratom) No 1605/2002 on the Financial Regulation applicable to the general budget of the European Communities (Official Journal of the European Communities L 357, 31.12.2002).
} 
hükümlerin çerçevesini belirlemiştir. Bu kurallar aynı zamanda hem genel prensipler hem de özel kurallar içermektedir. Kamu Alımları Anlaşması ihale sürecinde yer alan kuruluşları doğrudan muhatap alan çok sayıda hüküm içermekte ve bu anlamda çığır açan bir Anlaşma niteliğini taşımaktadır.

\subsection{Dünya Ticaret Örgütü Kuruluş Anlaşmasıı ve Eki Anlaşmalar}

DTÖ'nün faaliyet alanı ve fonksiyonları DTÖ Kuruluş Anlaşmasının II ve III. maddelerinde belirtilmiştir. Merkezi İsviçre'nin Cenevre kentinde bulunan DTÖ’nün başlıca faaliyetleri, Gümrük Tarifeleri ve Ticaret Genel Anlaşması $\left(\right.$ GATT ${ }^{14}$ ile diğer DTÖ anlaşmalarını yürütmek, uluslararası ticarete ilişkin anlaşmazlıkları çözmek, ticaret müzakereleri için forum oluşturmak, ulusal ticaret politikalarını izlemek ve gelişmekte olan ülkeler için teknik yardım sağlamaktır.

DTÖ Sistemindeki farklı anlaşmalar genel olarak, mallar, hizmetler ve fikri mülkiyet hakları olmak üzere üç alanda sınıflandırılabilir. KAA dâhil olmak üzere farklı DTÖ anlaşmaları, DTÖ'nün genel amaçlarını yansıtan bazı ortak amaçlara sahiptir. Dünya Ticaret Örgütü Sisteminin esasını oluşturan bu anlaşmalara ilişkin çok taraflı anlaşmaların özü, GATT'da ortaya konmuştur. GATT'ın temel amacı, uluslararası ticaretin serbestleştirilmesi yönünde mesafe alınması ve disipline edilmesidir. $\mathrm{Bu}$ kapsamda, ilk planda, tarife dışı engellerin kaldırılması ya da tarifeye dönüştürülmesi (tarifikasyon), tarifelerin karşılıklı olarak ve kademeli biçimde indirilmesi ve gümrük düzenlemelerinin uyumlaştırılması hedeflenmiştir. ${ }^{15}$ DTÖ'nün genel işlevi, Kuruluş Anlaşmasının ekinde yer alan anlaşmalara ve onlara dayalı diğer hukukî düzenleme araçlarına ilişkin konularda üyeleri arasındaki ticarî ilişkilerin yönetilip yönlendirilmesi için ortak bir kurumsal çerçeve sağlamaktır. ${ }^{16}$

Dünya Ticaret Örgütü Anlaşması (Final Act) ile kurulmuştur. Çok taraflı ticaret sisteminin yasal ve kurumsal temeli olan DTÖ 1 Ocak 1995 tarihinde faaliyete geçmiştir. Çok Taraflı Ticaret Anlaşmaları kapsamındaki tüm konular hakkında karar alma yetkisine sahiptir. ${ }^{17} 1947$ yılında imzalanan GATT, yalnızca uluslararası ticarete konu olan mallara ilişkin gümrük tarifeleri ile ilgili iken, Anlaşma, düzenlenen turlar sonucu zenginleştirilmiştir. 1994 yılında imzalanan DTÖ Anlaşması, GATT ve ekleri mal ticaretinin yanı sıra, hizmet ticaretini, fikri

\footnotetext{
${ }^{14}$ İngilizce adı "General Agreement on Tariffs and Trade" kelimelerinin baş harflerinin bir araya gelmesinden oluşan GATT, "Gümrük Tarifeleri ve Ticaret Genel Anlaşması" anlamına gelmektedir.

${ }^{15}$ Arat Tuğrul ve Erten Rifat, (2008), "DTÖ Hukuku ve Türkiye’ye Etkileri”, Dünya Ticaret Örgütü Doha Turu Çok tarafll Ticaret Müzakereleri ve Türkiye, M. Sait Akman ve Şahin Yaman (Ed.), Ankara, Tepav Yayınları No: 39, ss.358.

${ }^{16}$ DTÖ Anlaşması md XI. (1).

${ }^{17}$ DTÖ Anlaşması md IV/1.
} 
hakların ticari yönlerine ilişkin düzenlemeleri ve uyuşmazlıkların çözümünde uygulanacak kuralları kapsamaktadır. ${ }^{18}$

DTÖ, Anlaşmanın eklerinde yer alan anlaşmalarda ve bunlara bağlı yasal metinlerle ilgili konularda üye ülkeler arasında ticari ilişkilerin devamı için ortak kurumsal yapıyı oluşturmuştur. Ek-1, Ek-2 ve Ek-3'te yer alan Anlaşmalar ve bunlara bağlı olan hukuki metinler (Çok Taraflı Ticari Anlaşmalar) bu Kuruluş Anlaşmasının mütemmim cüz'üdürler ve tüm üyeleri bağlarlar. Ek-4'te yer alan Anlaşmalar (Çoklu Ticari Anlaşmalar) ve bunlara bağlı metinler ise, taraf olan üyeler açısından bu Anlaşmanın bir parçasını oluştururlar ve sadece imzalayan üyeleri bağlarlar.

Bununla birlikte, DTÖ Kuruluş Anlaşması ve ekindeki mütemmim cüz'ü sayılan anlaşmalar tüm DTÖ üyeleri açısından bağlayıcı olmakla birlikte Kamu Alımları Anlaşmasının uygulanması ve yorumlanması açısından önemlidir. KAA çoklu bir ticari anlaşma olması özelliği nedeniyle, bu anlaşmayla ilgili her değişiklik, karar alma veya anlaşmanın yorumlanması DTÖ Anlaşmasının genel kurallarına değil KAA'daki özel kurallar doğrultusunda gerçekleştirilir. ${ }^{19}$ Ancak, KAA ile ilgili olarak Taraf ülkeler arasında anlaşmazlık vuku bulması halinde DTÖ Anlaşmazlık Çözüm Organı anlaşmazlığı çözme yetkisine sahiptir. ${ }^{20}$ Ayrıca

${ }^{18}$ DTÖ Anlaşması kapsamında yer alan anlaşmalar ve bunlara bağlı hukuki metinler şunlardır:

EK 1: Çok Taraflı Ticaret Anlaşmaları

Ek 1 A: Mal Ticaretinde Çok Taraflı Anlaşmalar

- Gümrük Tarifeleri ve Ticaret Genel Anlaşması (GATT) 1994,

- Tarım Anlaşması,

- Bitki ve Hayvan Sağlığı Tedbirleri Uygulama Anlaşması,

- Tekstil ve Giyim Anlaşması (ATC),

- Ticaretle Bağlantılı Yatırım Tedbirleri Anlaşması (TRIMs),

- GATT'ın VI. maddesinin Uygulanmasına İlişkin Anlaşma

- GATT'ın VII. maddesinin Uygulanmasına İlişskin Anlaşma

- Sevk Öncesi İnceleme Anlaşması

- Menşe Kuraları Anlaşması

- İthalat Lisansları Anlaşması

- Sübvansiyonlar ve Telafi Edici Tedbirler Anlaşması

Ek 1 B: Hizmet Ticareti Genel Anlaşması ve Ekleri

Ek 1 C: Ticaretle Bağlantılı Fikri Mülkiyet Hakları Anlaşması

EK 2: Anlaşmazlıkların Çözülmesi Konusundaki Kural ve Yöntemleri Belirleyen Mutabakat Metni

EK 3: Ticaret Politikalarını Gözden Geçirme Mekanizması

EK 4: Çoklu Ticaret Anlaşmaları

- Çoklu Ticaret Anlaşmaları

- Sivil Uçak Ticaret Anlaşması

- Kamu Alımları Anlaşması (KAA)

- Uluslararası Süt Ürünleri Anlaşması (1997 yılı sonunda listeden çıkarılmıştır)

- Uluslararası Sığır Eti Anlaşması (1997 yılı sonunda listeden çıkarılmıştır)

${ }^{19}$ DTÖ Anlaşması md IX.5 ile X.10.

${ }^{20}$ KAA md XXII. 
DTÖ Anlaşması ile KAA arasında çelişki olması durumlarında lex specialis ilkesi gereği KAA'nın ilgili hükmüne üstünlük tanımak gerekmektedir. Oysa, DTÖ Anlaşmasının XVI.2 maddesi uyarınca DTÖ Kuruluş Anlaşması ve çok taraflı Anlaşmalar (Ek-1, Ek-2, Ek-3'teki anlaşmalar) arasında çelişki olması halinde böyle durumlarda DTÖ Anlaşması geçerli olacaktır. DTÖ, kuruluş Anlaşması ile ekinde yer alan Çok Taraflı Ticaret Anlaşmalarının uygulanmasını koordine etmekte ve denetlemektedir. Çoklu Ticaret Anlaşmalarının işlerliğini sağlamak için de gerekli çerçeveyi oluşturmaktadır. ${ }^{21}$

Gerek GATT gerekse GATS, KAA'nın anlaşılmasında kılavuzluk edebilecek, malların ve hizmetlerin ticareti ile ilgili üye devletlerin davranışları üzerinde bazı kısitlamalar koymaktadır. GATT'ın VI. maddesi, dampingli ithalat durumunda; genelde ihracatçı ülkenin iç piyasasındaki fiyatı ifade eden normal değerin altında bir ihracat fiyatı ile ithali yapılan ve ithalatçı ülkenin yerli sanayisine zarar veren ithal mallara karşı anti-damping harçları uygulama gibi tedbir alınmasına imkan sağlamaktadır. KAA'nın XII.2(h) maddesine göre; idarelerin ihale dokümanında, tekliflerin değerlendirilmesine yönelik olarak ihalenin karara bağlanması kriterleri içerisinde göz önünde bulundurulacak diğer unsurların yanı sıra KAA'na Taraf ülke ürünlerine uygulanacak ithalat vergileri, gümrük vergileri, anti-damping harc1 ve ödeme kuru gibi hususlara ilişkin açıklamalara yer verilmesi gerektiği belirtilmiştir.

DTÖ'nün çoklu ticaret Anlaşmalarından olan Kamu Alımları Anlaşması bu Anlaşmayı kabul etmemiş bulunan üyeler için yükümlülük veya hak yaratmayıp sadece bu anlaşmaya taraf olan üye ülkeleri bağlamaktadır. ${ }^{22} \mathrm{Bu}$ hak ve yükümlülükler; teknik şartnameler, ihale usulleri, isteklilerin yeterliliği, ihale dokümanları, değerlendirme kriterleri ve ihtilafların çözümüne yönelik usul ve hükümlerden oluşmaktadır. ${ }^{23} \mathrm{Bu}$ çalışma da bu hususları açıklayıcı bir çerçeve içerisinde yapılmıştır. DTÖ Anlaşmasının Ek-1, Ek-2 ve Ek-3'te yer alan Anlaşmalara taraf 153 üyesiyle karşılaştırıldığında DTÖ Kamu Alımları Anlaşması, daha düşük sayıda devlet tarafına sahiptir. Ayrıca DTÖ Kamu Alımları Anlaşmasının tarafları farklı taahhütler yapmışlardır. Örneğin, farklı taraf devletlerin DTÖ Kamu Alımları Anlaşmasının hangi hizmetleri veya ürünleri kapsadığına yönelik farklı taahhütleri vardır.

Dünya Ticaret Örgütü kapsamında Kamu Alımları Anlaşmasının yerini anlamak için DTÖ’nün faaliyetleri hakkında kısa bir değinmede bulunmak faydalı

${ }^{21}$ P. Van Den Bossche, (2005), The Law and Policy of the World Trade Organization-Text, Cases and Materials, Cambridge: University Press, s. 88.

${ }^{22}$ DTÖ Antlaşması md II (2).

${ }^{23}$ Sue Arrowsmith, The Law of Public and Utilities Procurement, 1996, London: Sweet \& Maxwell, 1st Edition, s. 776; Arrowsmith Sue, Linarelli John, Wallace Don, Regulating Public Procurement, 2000, Kluwer Law International, London, 1st Edition, s. 185. 
olacaktır. Dünya Ticaret Örgütü, çok taraflı ticaret sisteminin yasal ve kurumsal organıdır. DTÖ, hükümetlerin iç ticaret yasalarını ve düzenlemelerini nasıl yapacakları konusunda yasal bir çerçeve ortaya koymakta ve toplu görüşmeler ile müzakereler yoluyla ülkeler arasında ticari ilişkilerin geliştirildiği bir platform olmaktadır.

\section{DTÖ ve Uluslararası Ticaret}

DTÖ Kuruluş Anlaşmasının girişinde tarafların (üye devletlerin) ticaret ve ekonomik girişimcilik alanındaki ilişkilerinin yaşam standartlarını yükseltme, tam istihdamı ve gerçek gelir ile etkili talep hacminin önemli ve istikrarlı biçimde artışını garantileme, mal ve hizmet üretimi ile ticaretini arttırma, aynı zamanda dünyanın kaynaklarının sürdürülebilir kalkınma hedefine uygun olarak en iyi biçimde kullanımına izin verme, çevreyi korumaya ve bunu yapabilmenin araçlarını da ilgili ekonomik kalkınmanın farklı seviyelerindeki ihtiyaç ve ilgileriyle tutarlı biçimde geliştirmeyi dikkate alarak yapılması gerektiğini kabul ettikleri ifade edilmiştir. Ayrıca, gelişmekte olan ülkeler ile az gelişmiş ülkelerin, ekonomik kalkınma ihtiyaçlarıyla orantılı olarak uluslararası ticaretin gelişmesinde bir pay almalarını garantilemek amacıyla olumlu çabalara gereksinim olduğu belirtilmiştir.

Ticari engelleri azaltmayı amaçlayan farklı DTÖ anlaşmaları taraf devletlerarasındaki ticareti kolaylaştırmayı amaçlamaktadır. DTÖ sistemi, aynı zamanda gelişmekte olan ve en az gelişmiş olan ülkeler için uluslararası ticaretten bir pay almalarını garantilemek amacıyla aşağıda değinilen bazı özel istisnalar da öngörmektedir. DTÖ'nün amaçlarını yerine getirmek için yukarıda belirtilen bir dizi farklı anlaşma kabul edilmiştir. Bu farklı DTÖ anlaşmaları genel DTÖ Anlaşması olan ve DTÖ’yü kuran Marakeş Anlaşması'na ait eklerdir. DTÖ Anlaşması kapsamındaki anlaşmaların çoğu çok taraflıdır, yani bütün DTÖ üyelerini bağlayıcıdır. Bu anlaşmalara göre daha az sayıda imzalayanı olan KAA ise burada bir istisnadır ve yukarıda da belirtildiği üzere çoklu bir ticarî anlaşma olup sadece imzalayan ülkeleri bağlamaktadır.

\section{DTÖ Bă̆lamında Kamu Alımları Alanında Yaşanan Tarihi Gelişmeler}

Uluslararası piyasaların genel olarak serbestleştirilmesi bağlamında yukarıda da ifade edildiği üzere 1947 yılından beri GATT çerçevesi içerisinde bir uyumlaştırmaya gidilmişse de kamu ihale kurallarının bu anlamda GATT/DTÖ çerçevesi içerisinde serbestleştirilmesi daha henüz yeni bir öneme sahip olmuştur. Kamu ihaleleri, Gümrük Tarifeleri ve Ticaret Genel Anlaşmasının III. maddesinin 8. fikrası gereğince GATT'ın temel prensiplerinden ayrık tutulmuştur.

Kamu Alımları Anlaşması ilk olarak 1979 yılında Tokyo Turu müzakereleri sonucunda kabul edilip 1 Ocak 1981 yılında yürürlüğe girmiştir. Temel amacı ihale 
piyasalarını olabildiğince uluslararası rekabete açmaktır. KAA, kamu ihaleleri alanında liberalleşmenin geliştirilmesini temin etmek amacıyla bir çerçeve ortaya koymaktadır. Bu Anlaşma genel olarak, kamu alımlarıyla ilgili mevzuatın daha şeffaf olmasını sağlamak ve yabancı menşeli ürünler ile yabancı tedarikçiler karşısında yerli ürünler ve yerli tedarikçileri korumayı engelleyip bu açıdan ayrımcılığın önüne geçmeyi temin etmeyi hedeflemiştir. ${ }^{24} 1979$ tarihli ilk KAA kapsam olarak sınırlı ise de aslında uluslararası ekonomi ve ticaret açısından başka alanlarda daha önce katedilen yaklaşık 50 yıllık bir gelişmenin yansımasıdır. ${ }^{25} \mathrm{Bu}$ Anlaşma, Anlaşma'ya taraf ülkelerin kamu ihalelerindeki idari usul ve uygulamalar açısından ulusal firmalar ile yabancı firmalar arasında ayırımcı muamelede bulunmamasını ve Anlaşma'ya taraf ülkelerin firmalarına ve ürünlerine kendi ulusal firmalarından ve ürünlerinden (ayrıca bu Anlaşma'ya taraf ülkelerden herhangi birisinin firmaları ile ürünlerine) daha az avantajlı muamelede bulunulmamasını temin etmesi istenmiştir. ${ }^{26}$ Ayrıca bu hangi kurum ve kuruluşların bu Anlaşma'nın kapsamında kalacağı (Anlaşma hükümlerine göre ihalelerini gerçekleştireceği) hususu da Anlaşmaya taraf olan ülkelerin takdirine bırakılmıştır.

İlk olarak Tokyo Turunda müzakere edilmiş ve 1 Ocak 1981 yılında yürürlüğe giren Kamu Alımları Anlaşması'nda bilahare bazı değişiklikler yapılmış, daha önce sadece mal alımlarına yönelik olan düzenlemenin kapsamı genişletilerek hizmet alımları ve merkezi alım otoritelerine bağlı yerel alım kuruluşlarının yapacakları alımlar ile su, enerji, ulaştırma ve iletişim gibi genel hizmetlerle ilgili alımları da kapsamı dâhiline almış ve önceki Anlaşma metninde olmayan etkili bir uyuşmazlıkların halli mekanizması da öngörülerek Uruguay Turunda müzakeresi yapılan değişiklikleri içeren Anlaşma'nın son hali bu şekliyle 1 Ocak 1996 yılında yürürlüğe girmiştir. Bu yeni açılımla birlikte kamu alımlarının yıllık olarak gayri safi milli hâsıla içindeki payı ve toplam değeri bir önceki KAA'nın 1990-1994 yılları arasındaki yıllık ortalama değerlerine kıyasla 10 kat artmıştır. ${ }^{27}$ Aslında Kamu Alımları Anlaşması 1994 yılının Nisan ayında sonuçlanmış AB adına da AB

\footnotetext{
${ }^{24}$ Anlaşma metni için bkz. http://www.wto.org/english/docs_e/legal_e/gpr-94_e.pdf, Erişim: 15 Ocak 2014.

${ }^{25}$ C. Mccrudden, S. G. Cross, (2006), "WTO government procurement rules and the local dynamics of procurement policies: a Malaysian case study", European Journal of International Law, 17(1), ss. 151-185, s.155.

${ }^{26} 11$ Nisan 1979 tarihli Kamu Alımları Anlaşmasının Ulusal (Milli) Muamele ile Ayrımcılık Yapma Yasağıbaşlıklı II. maddesi. Bu anlaşmaya DTÖ'nün internet sayfasından da ulaşılabilir. http://www.wto.org/english/docs_e/legal_e/prewto_legal_e.htm, Erişim: 15 Ocak 2014.

${ }^{27}$ B. M. Hoekman, P. C. Mavrodis, (Ed.)(1997), "Law and Policy in Public Purchasing: The WTO Agreement on Government Procurement”, Hoekman B. M., Mavrodis P. C., Multilateralizing the Agreement on Government Procurement, kitabının içinde, Studies in International Trade Policy, Ann Arbor: University of Michigan Press, ss. 289-312, s. 296.
} 
Konseyi tarafından onaylanarak 1 Ocak 1996 yılında AB açısından yürürlüğe girmiştir.

DTÖ KAA, DTÖ üyesi olup Anlaşma'yı imzalayan ve Anlaşma kapsamında haklara ve yükümlülüklere sahip olan taraf devletlerin temsilcilerinden oluşan bir Kamu İhale Komitesi tarafından yönetilen çok taraflı bir anlaşmadır. 2014 yılının ilk yarısı itibariyle Anlaşma'ya taraf olan 42 ülke vardır. ${ }^{28}$ Bunlar; Kanada, 28 üye devletten oluşan Avrupa Birliği, Hong Kong (sadece bu bölge açısından Çin), İzlanda, İsrail, Japonya, Kore, Lihtenştayn, Hollanda'ya ait Aruba, Norveç, Singapur, İsviçre, Amerika Birleşik Devletleri, Tayvan ve Ermenistan'dan oluşmaktadır. Şu anda DTÖ KAA'na taraf olma süreci içerisinde müzakereler yapmakta olan 10 ülke de bulunmaktadır (Arnavutluk, Ermenistan, Çin, ${ }^{29}$ Gürcistan, Ürdün, Kırgızistan, Moldova, Karadağ, Umman, Yeni Zelanda ve Ukrayna). Anlaşma'ya taraf olmak açısından henüz müzakere sürecinde olmayan ve sadece gözlemci statüsünde olan 17 ülke bulunmaktadır (Arjantin, Avustralya, Bahreyn, Kamerun, Şili, Kolombiya, Hindistan, Endonezya, Malezya, Moğolistan, Panama, Rusya Federasyonu, Suudi Arabistan, Sri Lanka, Makedonya, Türkiye ve Vietnam'dan oluşan). Bunun yanı sıra 4 tane uluslararası örgüt de gözlemci statüsünde DTÖ Kamu Alımları Komitesinde bulunmaktadır. Bunlar; Uluslararası Para Fonu (IMF), Ekonomik İşbirliği ve Gelişme Teşkilatı (OECD), Birleşmiş Milletler Ticaret ve Kalkınma Konferansı (UNCTAD) ile Uluslararası Ticaret Merkezi (ITC).

DTÖ Kamu Alımları Anlaşması'na bu sayıda sınırlı katılımın olmasının sebeplerini Dischendorfer analiz etmiştir. Dischendorfer'e göre bunlar; KAA'nın "offset uygulamalarina" izin vermemesi neticesinde bazı ülkelerin kamu ihalelerinde kendi ekonomik ve sosyal politika araçlarını kullanamamaları (örneğin Avustralya ve Yeni Zelanda kamu ihalelerinde ulusal ürün ve firmalar lehine öngördükleri fiyat avantajını uygulamaya devam etmeyi istemektedirler), ihale usulleri ile ihale sürecine ilişkin ayrıntılı kuralların mevcudiyeti ile KAA'nın

${ }^{28}$ R. D. Anderson, A. C. Muller, K. Osei-Lah and P. Pelletier, (2012), "Assessing the value of future accessions to the WTO Agreement on Government Procurement: some new data sources, provisional estimates, and an evaluative framework for WTO members considering accession", Public Procurement Law Review, 4, ss. 113-138, s. 113. KAA'ya taraf olan ülkelerin listesi için bkz. http://www.wto.org/english/tratop_e/gproc_e/memobs_e.htm\#parties, Erişim: 15 Ocak 2014.

${ }^{29}$ F. Cao (2013), "Building up SME programmes in government procurement in China: legal structure, recent developments and the way forward towards the WTO-GPA", Public Procurement Law Review, 6, ss. 211-224; F. Cao, (2006), "Developments in China: the regulations implementing the Chinese Government Procurement Law, and progress towards GPA accession", Public Procurement Law Review, 6, ss. NA205-213, s.NA 212. Çin Aralık 2007 tarihinde DTÖ KAA'na taraf olmak için başvuruda bulunmuştur. Müzakere süreci bu açıdan devam etmekte olup Çin'in DTÖ KAA'na taraf olmasına $\mathrm{AB}$ ve $\mathrm{ABD}$ çok önem vermektedir. Ancak Çin'in KAA'ya taraf olması kendi iç mevzuatında çok temel değişiklikleri yapmasını da gerektirdiğinden müzakere sürecinin yakın bir dönemde bitmesi zor görünmektedir. 
öngördüğü denetim mekanizmasının karmaşık, maliyetli ve zahmetli olması neticesinde kamu ihalelerinde istenen paranın karşılığının alınması ile ekonomik verimliliğe ulaşılmasını engellemesi olarak belirtmiştir. ${ }^{30}$

Aşağıda da değinileceği üzere az gelişmiş ve gelişmekte olan ülkeler açısından KAA içerisinde öngörülen özel düzenlemeler de bu ülkelerin Anlaşma'ya taraf olmaları açısından yeterli görülmemiştir.

\section{Kamu Alımları Anlaşmasının Hukuksal Niteliği ve Temel Özellikleri \\ 2.1 KAA'nın hükümlerinin Taraf devletlerin İç Hukukunda doğrudan etkililiği}

Uluslararası bir Anlaşma'nın doğrudan etkili olması, belli şartların gerçekleşmesi durumunda Anlaşma kurallarının İç Hukukta herhangi bir uyarlama işlemine gerek kalmaksızın, Anlaşma'ya Taraf devletlerin hukuk sistemine dâhil olarak iç hukukta uygulanma imkânı bularak etkili olma kabiliyetidir. Doğrudan etkililiğin en önemli sonucu, bir uluslararası hukuk normunun bireylere ulusal merciler önünde ileri sürülebilecek haklar sağlamasıdır.

Doğrudan uygulanabilirlik ise, bir uluslararası hukuk kuralının, ulusal hukuk düzeninde, ulusal makamları bağlayıcı niteliğiyle uygulanma gücü kazanıp kazanamayacağına ilişkindir. DTÖ hukuku, bir üye devlet ülkesinde İç Hukuk açısından bir kere yürürlüğe girdikten sonar artık bağlayıcı biçimde uygulanabilirlik kazanmıştır. Ancak, bir anlaşma, uygulanabilir hale geldikten sonra da, ulusal mahkemede taleplere dayanak teşkil edebilme açısından, bu anlaşmanın ulusal hukuk düzeninde etkili olup olmadığını belirleme başka bir konudur ve ayrıca cevaplandırılmalıdır. ${ }^{31}$ Doğrudan etkililiğin söz konusu olduğu hallerde, Taraf devletlerin ilgili birimleri kararlarını, bireylerin bu konuda herhangi bir talebi olmasa da, re'sen doğrudan etkili uluslararası hukuk normları çerçevesinde vermelidir.

DTÖ Kuruluş Anlaşması'nın (DTÖ Anlaşması'nın) XI.(2) maddesine göre, DTÖ Anlaşması'nın eklerinde yer alan Çok Taraflı Ticaret Anlaşmaları ve bunlara bağlı hukukî metinler tüm üye devletleri bağlar. Uluslararası hukuk bağlamında üye devletlerin ulusal hukuk organlarının bunun gereğini nasıl yerine getireceği her üyenin kendi İç Hukuk düzeninde alacağ Uluslararası hukukun ulusal hukuk düzenlerinde uygulanma yeteneği kazanması konusundaki hâkim anlayışa göre DTÖ Anlaşması ve ekindeki Anlaşmalar üye devletlerde doğrudan etkili kabul edilmemektedir. Özellikle, Avrupa Birliği, ABD, Japonya, Kanada ve Çin gibi ülkeler, DTÖ hukukunun hükümlerine doğrudan etki

\footnotetext{
${ }^{30}$ M. Dischendorfer, (2000) "The existence and development of multilateral rules on government procurement under the framework of the WTO", Public Procurement Law Review, 1, ss. 1-38, s.28.

${ }^{31}$ T. Arat ve E. Rifat, s. 394.
} 
tanımayı reddetmişlerdir. Dolayısıyla, genellikle, DTÖ Anlaşmalarındaki kuralların bireysel taleplere, özellikle ulusal mahkemelerde dayanak teşkil etmesi veya bu kurallara aykırı iç hukuk yasalarının geçersiz kılınmasına gerekçe oluşturması için uygulama mevzuatının yürürlüğe konması gerekecektir. ${ }^{32}$

KAA’nın kendi metni içerisinde, Taraf ülkelerin İç Hukuk düzenlerinde KAA'ya doğrudan etki tanımaları gerektiğine dair açık bir düzenleme yoktur. Ayrıca KAA’nın bazı hükümlerinin de Taraf ülkelerin İç Hukuklarında bir iç düzenleme yapmaya gerek kalmaksızın 'doğrudan uygulanabilir' olduğuna dair bir düzenleme de yoktur. Uluslararası hukuka göre eğer KAA'na Taraf olan ülkeler kendi iç hukuk düzenlerinde KAA'na doğrudan etki tanımak zorunda iseler Avrupa Birliği ve üye devletler de Avrupa Birliği içerisinde Kamu Alımları Anlaşmasında doğrudan etki tanımak durumundadır. ${ }^{33}$

DTÖ Kuruluş Anlaşması ve ekleri olan Anlaşmalar uluslararası hukukun düzenleme araçlarındandır. Viyana Antlaşmalar Hukuku Sözleşmesi’nin “iç hukuk ve antlaşmalara riayet" başlıklı 27.maddesinde; "Bir taraf bir antlaşmayı icra etmeme gerekçesi olarak iç hukukunun hükümlerine başvuramaz" hükmü yer almaktadır. $\mathrm{Bu}$ nedenle uluslararası bir anlaşmaya Taraf olanlardan biri, antlaşmanın icra edilmemesini haklı göstermek amacıyla iç hukukunun hükümlerini öne süremez. DTÖ Kuruluş Anlaşmasının XVI.(4) maddesi; her üye devletin, yasalarının ve idarî usullerinin DTÖ Anlaşması ekindeki Anlaşmalarda öngörülen yükümlülükleriyle uyumunu güvence altına almasını gerektirir. Dolayısıyla, bir DTÖ üyesinin İç Hukuku, o devletin DTÖ üyeliğinden doğan yükümlülüklerini yerine getirmemesinin mazeretini teşkil edemeyecektir.

Uluslararası hukuka göre, devletler, taraf oldukları uluslararası anlaşmalara uymak, bu anlaşmalardan doğan yükümlülüklerin gereğini yerine getirmek sorumluluğu altındadır. Bir uluslararası anlaşmaya taraf olan devlet açısından bu sorumluluk, kendi iç hukukunda, bu anlaşmadan doğan yükümlülüklerine ters düşen kurallar ittihaz etmemesi şeklinde kendini gösterir. Bu nedenle, devletler, ulusal hukuklarını uluslararası anlaşmalardan doğan yükümlülükleriyle uyumlu hale getirmek ödevindedir. Bir devletin uluslararası anlaşmalardan doğan yükümlülükleriyle ilgili bu ödevi yerine getiriş biçimi kendisine kalmıştır. Devlet, bu ödevini uygun görürse, yürürlüğe koyduğu anlaşmaya 'doğrudan etki', hatta yasalara nazaran üstünlük tanıyarak yapar; ihtiyaç duyarsa, anlaşmanın gereklerini iç hukuka yansıtan yasalar ve düzenleyici işlemler veya idarî düzenleme ve usuller öngörerek yapar. ${ }^{34}$

${ }^{32}$ T. Arat ve R. Erten, s. 395.

${ }^{33}$ D. D. Dahlgaard, (1999), A Harmonization of the National Judicial Review of the Application of European Community Law, Kluwer Law International, The Hague-London-Boston, s. 78.

${ }^{34}$ T. Arat ve R. Erten, s. 392 
Kamu Alımları Anlaşmasının XX. maddesinde şikâyet prosedürüne ilişkin genel ve düzenleyici mahiyette bazı kurallar belirlenmiştir. Buna göre; Anlaşmaya taraf ülkelerden her biri, tedarikçilerin iddia edilen Anlaşma ihlallerine itiraz edebilmesini teminen zamanında, ayrımcı olmayan, şeffaf ve etkili denetim usulleri sağlayacaklar ve tarafların her biri kendi itiraz yöntemlerini yazılı olarak belirleyecek ve genel olarak bunlara ulaşılmasını sağlayacaktır. Ayrıca KAA'nın XX. maddesinin 6. fikrasına göre, tedarikçilerin yapacağ mahkeme veya alımın (ihalenin) sonuçlarından herhangi bir çıkarı olmayan ve vazife süresince dış etkiler açısından güvenilir üyeleri olan bir inceleme organı tarafından bakılacağı belirtilmiştir. Bu hükümler nedeniyle KAA bizatihi kendi metni temelinde tedarikçiler, doğrudan doğruya ihaleyi gerçekleştiren idarenin bulunduğu Taraf ülke mahkemeleri ile inceleme organlarında KAA hükümlerini ileri sürebilir. ${ }^{35}$

KAA hükümlerinin açık olarak doğrudan uygulanabilir olduğuna dair KAA'nın hiçbir yerinde bir düzenleme yapılmış değildir. Bazı KAA hükümleri tam, açık ve koşulsuz nitelikte olsa bile bu hükümlere de yönelik olarak Taraf ülkelerin kendi iç hukuklarında doğrudan etki tanıma zorunlulukları yoktur. KAA'nın ne şekilde İç Hukukun bir parçası sayılacağına dair husus tamamen Taraf ülkelerin inisiyatifine bırakılmış bir konudur. Bununla birlikte, KAA'nın İç Hukuka aktarımının yöntemi ile dahli KAA'nın gerekliliklerini de karşılaması gerekmektedir. Kamu Alımları Anlaşmasının İç Hukukun bir parçası haline getirilmesi neticesinde, KAA'nın XX. maddesi uyarınca Anlaşmaya taraf ülkelerden her biri, tedarikçilerin iddia edilen KAA'nın İç Hukuka aktarılan hükümlerinin ihlallerine karşı ulusal mahkeme veya merciler nezdinde itirazda bulunabilmesinin temini gerekmektedir. Ancak bu yaklaşım ile tedarikçilerin KAA'nın bizatihi kendi metni temelinde, doğrudan doğruya ihaleyi gerçekleştiren idarenin bulunduğu Taraf ülke mahkemeleri ile inceleme organlarında KAA hükümlerini ileri sürmeleri aynı şey değildir. Zira, bu ikinci durumda, Taraf ülkelerin KAA metnini kendi İç Hukuklarına aktarıp aktarmamalarına veya yanlış aktarmalarına bakılmadan tedarikçilere Taraf ülke mahkemeleri ile inceleme organlarında KAA hükümlerini ileri sürme imkanı verilmesi söz konusudur.

Mevcut DTÖ Kuruluş Anlaşmasının müzakeresi aşamasında İsviçre'nin, Uruguay çok taraflı müzakereleri (1986 ila 1994 arası) neticesinde yapılan Anlaşmalara doğrudan etki tanınması yönünde sunduğu öneri ülkelerin çoğu tarafından reddedilmişti. $\mathrm{Bu}$ doğrultuda Kamu Alımları Anlaşmasına Taraf ülkelerin İç Hukuklarında doğrudan etki tanıma zorunluluklarının olmadığ söylenebilir. Bununla birlikte KAA hükümlerine doğrudan etki tanınma imkânı açık olarak KAA metni içerisinde ortadan kaldırılmamıştır. Uluslararası hukuka

${ }^{35}$ D. D. Dahlgaard, ss. 78-79. 
göre Taraf ülkelerin KAA hükümlerine kendi İç Hukuklarında doğrudan etki tanıması her bir Taraf ülkenin kendisine kalmış bir konudur. Avrupa Birliği'nin diğer KAA Tarafı ülkeler karşısında KAA hükümlerine doğrudan etki tanıma zorunluluğu yoktur. $^{36}$

DTÖ Kuruluş Anlaşması ve eki Anlaşmaları Avrupa Birliği adına AB Konseyi tarafından 94/800/AT sayılı Karar ile kabul edilmiştir. ${ }^{37}$ 94/800/AT sayılı Kararın giriş kısmında DTÖ Kuruluş Anlaşmasının doğrudan etkiye sahip olmadığı açıkça belirtilmiştir. Bu değerlendirme sadece DTÖ Kuruluş Anlaşmasının ekindeki Çok Taraflı Ticari Anlaşmalar açısından değil aynı zamanda Çoklu Ticari Anlaşmalardan olan KAA açısından da söz konusudur. Bununla birlikte, Dahlgaard Dingel gibi kimi müellifler Konseyin bu ifadesine rağmen KAA'nın bazı hükümleri itibariyle doğrudan etkiye sahip olabileceği ihtimalini reddetmemiştir. Buna göre; AB'nin üçüncü ülkelerle imzaladığı uluslararası anlaşmaların tam, açık, kesin ve koşulsuz olan hükümlerinin doğrudan etki doğurmaya elverişli olabileceğinin Avrupa Birliği Adalet Divanının (ABAD) içtihadı ile de sabit olduğu, ${ }^{38}$ bu açıdan KAA'nın bazı hükümlerinin bu nitelikte olduğu, ayrıca KAA'nın amacı ile niteliğine bakıldığında da bu hükümlere doğrudan etki tanımanın söz konusu amaca uygun düşeceği, karş1lıklılık prensibinin de bu konuda (doğrudan etkiye haiz olma konusunda) kesin bir kanaati ortaya koymak açısından kesin belirleyici bir kriter olmadığı belirtilmiştir. ${ }^{39}$ Ayrıca $\mathrm{AB}$ hukukunda, ikincil mevzuat olan yönergelerde KAA'nın doğrudan etkiye sahip olmadığının belirtilmesinin bu sonucu etkilemeyeceği, zira AB'nin üçüncü ülkelerle imzaladığı uluslararası anlaşmaların birincil mevzuat içerisinde sayıldığından ikincil mevzuatın birincil mevzuattaki bir sonucu değiştirmeyeceği belirtilmiştir.

Aşağıda da belirtildiği gibi KAA'nın 6 Nisan 2014 tarihi itibariyle yürürlüğe giren ${ }^{40}$ XVIII(1) maddesinde ulusal iç denetim sistemine ilişkin olarak; ya

${ }^{36}$ D. D. Dahlgaard, ss. 79-80.

${ }^{37}$ OJ L 336, 23.12.1994, s. 1.

${ }^{38}$ AB'nin üçüncü ülkelerle imzaladığı uluslararası anlaşmaların bazı hükümlerinin doğrudan etkiye sahip olduğuna ilişkin ABAD kararı için bkz.Case 12/86 Demirel [1987] ECR 3719, para. 14. Ayrıca bkz. Kaczorowska A., (20139, European Union Law, Published by Routledge-Cavendish, Abingdon, Oxon, 3rd edition, s. 298.

${ }^{39}$ D. D. Dahlgaard, ss. 81-87.

40 Önceki KAA’nın XXIV. (7) (b) maddesinde tarafların Anlaşmanın geliştirilmesi amacıyla müzakere yapmalarına olanak verilmişti. Bu hüküm doğrultusunda yapılan müzakereler neticesinde 15 Aralık 2011'de KAA'nın Taslak Metniyle ilgili Karar ortaya çıkmıştır. Bu Karar da 30 Mart 2012 tarihinde kabul edilerek taraf ülkelerin onayına sunulmuştur. KAA'nın Taslak Metninin taraf ülkelerin üçte ikisi tarafından iç mevzuatı doğrultusunda kabulü ve onaylanmasının yürürlüğe girmesi öngörülmüştü. Bu doğrultuda söz konusu Taslak Metin 6 Nisan 2014 tarihi itibariyle yürürlüğe girmiştir. KAA’nın yeni metni için bkz. http://www.wto.org/english/tratop_e/gproc_e/gp_gpa_e.htm, Erişim: 15 Ağustos 2014. Bu konuda bkz. R. D. Anderson, (2012), "The conclusion of the 
Anlaşma'daki kuralların ihlal edilmesi halinde bir denetim başvurusu yapılabilmesine yönelik iç hukukta buna ilişkin bir düzenleme yapılması ya da bu yönde iç hukukta Anlaşma kurallarının ihlal edilmesi halinde bir denetim başvurusunda bulunma imkânı yoksa Taraf ülke tarafından Anlaşma kurallarının uygulanmasıyla (iç hukuka aktarılması konusunda veya yanlış uygulanmasıyla) ilgili bir uyumsuzluk başvurusu yapılmasına imkân getirilmesi gerekmektedir. Aslında ilk önlemle ilgili önceki KAA'da düzenleme var ise de bu düzenleme doğrultusunda Taraf ülkelerin çoğu kendi iç hukuk sistemlerinde Anlaşma'nın ihlaline karşı doğrudan başvuruda bulunma imkânını getirmemiştir. Bu açıdan KAA'nın yeni düzenlemesi sonucunda burada bir doğrudan etkiden değil de menfi etkinin (dolaylı etki) daha açık ifade edilmesinden bahsedilebilir. Menfi etki şu anlama gelmektedir ki; iç hukukta Anlaşma kurallarının ihlal edilmesi halinde bir denetim başvurusunda bulunma imkânı yoksa veya Taraf ülke tarafından iç hukuka aktarım yanlış yapılmış veya Anlaşma yanlış uygulanmışsa, bireylerce Anlaşma kurallarının uygulanmasıyla ilgili ulusal mahkemeye bir uyumsuzluk başvurusu yapılarak, iç hukuk kuralının Anlaşma'ya uygun yorumlanması veya Anlaşma kuralıyla çatışan iç hukuk kuralının (hak ve borç doğurma anlamında) tatbik edilmemesi şeklinde bir etki doğurması olarak algılamak gerekmektedir.

DTÖ Kamu Alımları Anlaşması'na Taraf ülkelerde doğrudan etki tanınması, KAA hükümlerinin Taraf ülkelerde etkililiğini ve icra gücünü artıracaktır. Böylece, Taraf devletler, KAA hükümlerine uyup uymama konusunda kısıtlanmış olacaktır. Zira Taraf devletler doğrudan etki doktrini neticesinde KAA'ya uyma bakımından, artık doğrudan doğruya kendi ulusal mahkemelerinin denetimi altına girmiş olacaklardır. Ancak, DTÖ KAA'nın, son haliyle bile Taraf ülkeler açısından doğrudan etkisinden bahsetmek mümkün değildir. Yukarıda da açıklandığı üzere KAA'nın yeni metnindeki söz konusu düzenleme ancak menfi etkinin (dolaylı etkinin) daha açık olarak ifade edilmesi anlamına gelmektedir.

\subsection{KAA'nın Avrupa Birliği Adalet Divanı tarafından yorumlanması}

$\mathrm{AB}$ hukukunun uygulanması ulusal mahkemeler aracılığıyla gerçekleşmektedir. $\mathrm{Bu}$ yüzden ulusal mahkemeler bir anlamda 'AB mahkemesi' haline dönüştürülmüştür. $\mathrm{Bu}$ çerçevede ulusal mahkemeler önlerine gelen bir uyuşmazlıkta $\mathrm{AB}$ hukukunu öncelikle uygulamak, $\mathrm{AB}$ hukuku ile çelişen tüm ulusal normları göz ardı etmek ve $\mathrm{AB}$ hukuku ile kişilere tanınan hakların kullanılmasını güvence altına almak durumundadırlar. Ulusal mahkemeler, $A B$ hukukunu uygulamayan devlet aleyhine açllacak iptal ve tazminat davalarında ve

renegotiation of the World Trade Organization Agreement on Government Procurement: what it means for the Agreement and for the world economy", Public Procurement Law Review, 3, ss. 83-94; W. Ping, (2012), "The renewed momentum for the expansion of the WTO Agreement on Government Procurement”, Public Procurement Law Review, 4, ss. NA157-159. 
$\mathrm{AB}$ rekabet hukukuna aykırı eylem ve işlemlerin geçersizliğine ilişkin davalarda yetkili mahkemeler olarak öngörülmüştür. ${ }^{41}$

Bununla birlikte ulusal mahkemeler $\mathrm{AB}$ normlarının geçerliliği ve yorumu konusunda karar verme yetkisine sahip olmayıp bu konularda karar verme yetkisi münhasıran Avrupa Birliği Adalet Divanı'na (ABAD) aittir. AB hukukunun uygulanması ulusal mahkemeler tarafindan gerçekleştirilmekte iken dava konusu olayda uygulanacak normun yorumu ve geçerliliği, normu uygulayacak olan ulusal mahkeme tarafından değil ABAD tarafından kesin karara bağlanmaktadır. Ancak normun yorumunu yapmaya yetkili olan ABAD, soyut normu somut olaya uygulamamakta, bu işi uyuşmazlıkla ilgili kararı verme yetkisine sahip olan ulusal mahkeme yapmaktadır. Ön karar yöntemi olarak adlandırılan bu yöntem, AB hukukunun uygulanmasında farklı yorumların önüne geçilmesi ve yorum birliğine ulaşılması açısından önemlidir.

ABİHA'nın 267. maddesi (eski AT Antlaşmasının 234. maddesi) dâhilinde $\mathrm{ABAD}, \mathrm{AB}$ 'nin taraf olduğu uluslararası antlaşmaların yorumu, $\mathrm{AB}$ kurumlarının tasarruflarının geçerliliği ve yorumu konularında yetkilidir. $\mathrm{Bu}$ nedenle, $\mathrm{AB}$ tarafından kabul edilen DTÖ Kamu Alımları Anlaşması AB hukukunun bir parçası kabul edilmekte ve AB hukukuna geçirilen bu uluslararası anlaşmanın yorumu ön karar davasının konusunu da oluşturur. AB'nin taraf olduğu uluslararası anlaşmaların yorumu konusunda ABAD'ın yetkili olduğu kabul edilmekle birlikte bu uluslararası anlaşmaların geçerliliği konusu ön karar davası kapsamı dışında kalmaktadır. $^{42}$

DTÖ Kamu Alımları Anlaşmasının içerisinde bu anlaşmayı imzalayan ülkeler açısından ABİHA'nın 267. maddesi gibi bir yöntem olmaması nedeniyle KAA tarafı ülkelerin ulusal mahkemelerinin KAA'nın kurallarının yorumlanması açısından ABİHA'da olduğu gibi yorum birliğini sağlayıcı mekanizma öngörülmemiştir. Bununla birlikte, DTÖ Kamu Alımları Anlaşması AB hukukunun bir parçası olduğundan $\mathrm{AB}$ üyesi ülkelerin ulusal mahkemeleri KAA’nın yorumu konusunda ABAD'a başvurabilirler.

Kamu Alımları Anlaşması AB tarafından AB kurumlarının bir tasarrufu olarak yürürlüğe konulduğundan ABAD ABİHA'nın 267. maddesinin birinci paragrafı bağlamında bu anlaşma hükümlerinin yorumu konusunda ön karar davası yöntemiyle karar vermeye yetkilidir. DTÖ Kamu Alımları Anlaşması hem AB üyesi devletler hem de $\mathrm{AB}$ tarafından birlikte imzalanan bir anlaşmadır. Kamu ihalesi konusunun üye devletler ile AB'nin paylaşılmış yetki alanında kalan bir

\footnotetext{
${ }^{41}$ H. Adaoğlu, (2006), AT Hukukunun Üye Ülkelerde Uygulanmasında Ulusal Mahkemeler ve ATAD İlişkisi, Ankara Üniversitesi Avrupa Toplulukları Araştırma ve Uygulama Merkezi Araştırma Dizisi No: 24, Ankara Üniversitesi Basımevi, Ankara, s. 147.

${ }^{42}$ H. Adaoğlu, s. 153.
} 
konu olması itibariyle Kamu Alımları Anlaşması hem üye devletler hem de $\mathrm{AB}$ tarafindan birlikte taraf olunan bir anlaşmadır. Nitekim AB'ye 1 Mayıs 2004 tarihinde tam üye olan 10 Merkezi ve Doğu Avrupa ülkesinin AB üyelikleri kabul edilir edilmez ilk imzaladıkları uluslararası anlaşma DTÖ Kamu Alımları Anlaşması olmuştur. Aynı süreç AB'ye 1 Ocak 2007 tarihinde tam üye olan Romanya ve Bulgaristan açısından da yaşanmıştır. ${ }^{43} \mathrm{Bu}$ açıdan DTÖ KAA karma anlaşma türündeki bir uluslararası anlaşmadır. Zira bu anlaşma konusu olan alan Birliğin münhasır yetkisi içerisinde kalan bir alan değildir ve bu alandaki konularla ilgili uluslararası platformdaki temsil, hem üye devletler hem de AB tarafindan birlikte yakın bir işbirliği dâhilinde yapılır. Nitekim ATAD DTÖ Anlaşması'nın kabulüne ilişkin 1/94 say1lı görüşünde şu görüşü ortaya koymuştur.

“...bir uluslararası anlaşmanın konusu kısmen üye devletler kısmen AB'nin yetkisi dahilinde kalmakta ise, bu nitelikteki bir uluslararası anlaşmanın gerek müzakereleri ile anlaşmanın sonuçlandırılmasında gerekse bu uluslararası anlaşmanın yükümlülüklerinin yerine getirilmesine ilişkin olarak üye devletler ile $A B$ arasında yakın bir işbirliğinin temin edilmesi son derece önemlidir. Bu yakın işbirliği yükü̈mlülüğ̈̈, Topluluğun uluslararası ortamlarda temsili yönünden Birlik olmasınin bir gereğidir..."44

\subsection{Kamu Alımları Anlaşmasının Hukuki Yorumu}

DTÖ Kamu Alımları Anlaşması uluslararası bir anlaşma olup bu anlaşmanın yorumunun da Viyana Antlaşmalar Hukuku Sözleşmesinin "Antlaşmaların yorumu" başlıklı kısmın 31(1) maddesindeki esasları doğrultusunda yapılması gerekir. Bu düzenlemeye göre; "Bir antlaşma, hükümlerine antlaşmanın bütünü içinde konu ve amacının ışığında verilecek olağan manaya uygun şekilde iyi niyetle yorumlanır". DTÖ Kamu Alımları Anlaşması metninin de antlaşmanın bütünü içinde konu ve amacının ışığında verilecek olağan manaya uygun şekilde iyi niyetle yorumlanması gerekir.

Anlaşmanın girişi, ekleri, anlaşmaya bağlı diğer anlaşmalar veya belgeler de yorum araçlarıdır. DTÖ Kamu Alımları Anlaşmasının yorumunda bağlam olarak bu anlaşma DTÖ Anlaşması'nın ekinde yer alan bir anlaşma olması itibariyle DTÖ Kuruluş Anlaşması ve DTÖ Kuruluş Anlaşmasının 2 no'lu ekinde yer alan Uyuşmazlıkların Çözümünün Kural ve Yöntemleri Hakkında Mutabakat Metni bağlamında yorumlanması gerekmektedir. ${ }^{45}$ Buna ek olarak, tamamlayıcı yorum

\footnotetext{
${ }^{43}$ KAA'nın XXIV: 6(a) maddesi doğrultusunda bu işlemler gerçekleştirilmiştir.

${ }^{44}$ ATAD, 1/94 sayılı görüş, paragraf [108].

${ }^{45}$ Viyana Antlaşmalar Hukuku Sözleşmesinin “Antlaşmaların yorumu” başlıklı kısmın 31(2) maddesinde " 2 . Bir antlaşmanın yorumu bakımından, (antlaşmanın) bütünü, girişini ve eklerini içine alan metne ilaveten, aşağıdakileri kapsar:

a- antlaşmanın akdedilmesi ile bağlantılı olarak bütün taraflar arasında yapılmış olan antlaşmayla ilgili herhangi bir anlaşma;
} 
araçlarını düzenleyen Viyana Antlaşmalar Hukuku Sözleşmesinin 32.maddesine göre, belirsizlik durumunda anlaşmanın hazırlık çalışmaları ve yapıldığı koşullar da değerlendirilebilir.

DTÖ Kamu Alımları Anlaşması orijinal metin olarak İngilizce, Fransızca ve İspanyolca dillerinde kabul edilmiştir. KAA'nın orijinal metninin yorumu konusunda esas alınacak metnin birden fazla dil olması nedeniyle terimlerle ilgili aynı anlamın verilmediği durumlarda Viyana Antlaşmalar Hukuku Sözleşmesinin 33. maddesi doğrultusunda çözümlenmesi gerekir.

Buna göre;

"1. Bir antlaşma iki veya daha fazla dilde tevsik edildiği zaman, görüş ayrılığı olması halinde, belirli bir metnin üstün tutulacağını metnin kendisi öngörmedikçe veya taraflar öyle kararlaştırmadıkça, her bir dildeki metin aynı şekilde geçerlidir.

2. Metnin tevsik edildiği dillerden gayrı bir dildeki bir antlaşma sureti, ancak antlaşmanın öngörmesi veya tarafların kabul etmesi halinde geçerli bir metin telakki edilir.

3. Antlaşma hükümlerinin her bir geçerli metinde aynı manayı taşıdığı farz edilir.

4. Birinci paragrafa göre, belirli bir metinin üstün tutulduğu durumlar saklı kalmak üzere, geçerli metinler arasında yapılan bir karşılaştırma, 31. ve 32. maddelerin uygulanmasının ortadan kaldırmadığı bir anlam farkı ortaya koyarsa, antlaşmanın konu ve amacı göz önünde tutulduğunda metni en iyi uzlaştıran anlam benimsenecektir”.

Bu açıdan DTÖ KAA'nın yorumunda görüş ayrılığı olması halinde geçerli metinler arasında yapılan bir karşılaştırma, 31. ve 32. maddelerin uygulanmasının ortadan kaldırmadığı bir anlam farkı ortaya koyarsa, antlaşmanın konu ve amacı göz önünde tutulduğunda metni en iyi uzlaştıran anlam benimsenecektir.

$\mathrm{Bu}$ çerçevede; KAA'nın yorumunda Viyana Antlaşmalar Hukuku Sözleşmesinin iyi niyet ilkesine, anlaşma terimlerinin olağan anlamının aranması ilkesine, anlaşmanın konusuna ve amacina uygunluk ile etki doğurma ilkesine, anlaşmanın bağlamının göz önünde tutulması ilkesine (uygun yorum) ve tamamlayıcı yorum olarak anlaşmanın hazırlık çalışmaları ile anlaşmanın yapıldığ 1 koşullara dikkat edilmesi gerekir. Yukarıda belirtilen yorum kuralları çerçevesinde KAA, dar ve geniş yorum, benzetme yoluyla yorum, aksiyle kanıtlama yoluyla yorum vb. değişik yöntemlerle yorumlanabilir.

Avrupa Birliği her ne kadar Viyana Antlaşmalar Hukuku Sözleşmesine taraf değilse de ABAD'ın önüne gelen bir uyuşmazlıkla ilgili olarak söz konusu

b- antlaşmanın akdedilmesi ile bağlantılı olarak bir veya daha fazla tarafça yapılan ve diğer taraflarca antlaşmayla ilgili bir belge olarak kabul edilen herhangi bir belge" düzenlemesi bulunmaktadır". 
sözleşmenin 31 ila 33. maddeleri doğrultusunda yorum geliştirmesi beklenmektedir. DTÖ Kamu Alımları Anlaşmasının XXII.(1) maddesi hükmü uyarınca DTÖ Kuruluş Anlaşmasının 2 no'lu ekinde yer alan Uyuşmazlıkların Çözümünün Kural ve Yöntemleri Hakkında Mutabakat Metninin KAA'ya uygulanması gerekir. Söz konusu Mutabakat Metni uyarınca da 'uluslararası kamu hukukunun yorumuyla ilgili örf ve adet hukuku kuralları' Kamu Alımları Anlaşmasının uygulanması ve yorumlanmasında kullanılır.

AB mevzuatını yorumlamada ABAD'ın etkinliği son derece önemlidir. Karar oluşturmakla ve sorunu giderici bir çözüm bulmakla mükellef bir mahkemenin var olan soyut metinleri olaya tatbik ederken kullanacağı yorum yöntemleri önem teşkil etmektedir. ABAD, kamu ihalesi alanındaki $\mathrm{AB}$ hukuku kurallarını; kural metninin analizi (metinsel yorum), veya kuralın bulunduğu bağlam itibariyle (bağlamsal yorum) ya da kuralın amacını öne çıkararak (teleolojik yorum-amaçsal yorum) değerlendirmekte ve yorumlamaktadır. ABAD genellikle yazılı hukuki kurallar oluşturulurken neyi amaçladıklarına ve Topluluğun ihtiyaçlarına göre bir yorum yöntemini(teleolojik metod) sıklıkla uygulamıştır. Bununla birlikte Divan bu üç yorum metodunun birbirleri arasında hiyerarşik bir üstünlük içerisinde uygulama geliştirmemiştir. ${ }^{46}$

\subsection{Genel prensipler}

Anlaşmanın genel hükümler ve yükümlülükler şeklinde ayırabileceğimiz iki önemli unsuru bulunmakla birlikte Anlaşmaya taraf olan üye ülkelerin ihale yaparken bu Anlaşmaya uymaları gereken kuruluşlarının listeleri de mevcuttur. Kamu Alımları Anlaşması kamu ihaleleri alanında daha fazla serbestleşmenin sağlanması anlamında maddî ve usulî hükümlerin bir çerçevesini teşkil etmektedir. $^{47}$

Uruguay turunda kamu ihalelerine ilişkin müzakerelerde bölgesel olarak kamu ihalelerinde rekabeti ve şeffaflığı temin etmeyi hedefleyen Avrupa Birliği ihale kuralları önemli derecede bir esin kaynağı olmuştur. Bu yüzden aşağıda da görüleceği gibi Kamu Alımları Anlaşması hükümleri ile Avrupa Birliği ihale kuralları arasında yapısal olarak benzerlikler bulunmaktadır. ${ }^{48}$ AB'nin kamu ihalesi alanında Birlik düzeyinde kamu ihalelerinin rekabete ve katılıma açılması ile bu alanda şeffaflığın temin edilmesine yönelik uyumlaştırma yönergeleri (direktifleri) ile DTÖ KAA metni açısından bu benzerlik doğal karşılanmalıdır.

\footnotetext{
${ }^{46}$ D. D. Dahlgaard, s.24

${ }^{47}$ Kamu Alımları Anlaşmasının önsözünün ilk paragrafı

${ }^{48}$ G. Roebling, (1999) 'Invoking the Agreement on Government Procurement', Public Procurement Law Review, 4, ss. 187-208, s. 188.
} 
Karşılaştırma yapılacak olursa GATT'ın içinde yer alan temel ilkelerin Kamu Alımları Anlaşmasının da temelini oluşturan temel ilkeler olduğunu görmekteyiz. Bunlar; ulusal (milli) muamele kuralı ${ }^{49}$, en çok kayırılan ülke prensibi ${ }^{50}$, ayrımcılık yasağ ${ }^{51}$ ve şeffaflı ilkesi ${ }^{52}$ olarak bilinmektedir.

\section{En çok kayırılan ülke prensibi}

GATT'ın önemli kuralları arasında yer alan “En Çok Kayrılan Ülke” kuralına göre, bir ülkeye sağlanan kolaylık, muafiyet ya da verilen taviz, ayırım yapılmadan Anlaşmaya taraf bütün diğer üye ülkelere de aynen geçerli kılınmalıdır (Genelleştirilmiş tercihler sistemi, dampingli ve sübvansiyonlu mallara uygulanan mukabil tedbirler ile kurallara uygun gümrük birliği ve serbest ticaret bölgesi anlaşmaları bu kuralın istisnalarıdır). Ayrıca, bu ilke gereği, bir DTÖ üyesi devlet, üçüncü ülkelere tanıdığı kolaylık sağlayıcı kural ve lehte uygulamayı DTÖ üyelerine de ek ve özel bir koşul eklemeksizin derhal uygulamak zorundadır. ${ }^{53} \mathrm{Bu}$ kural DTÖ Anlaşmalarının temel prensiplerinden biri olmakla birlikte bu prensibin her Anlaşma yönünden farklı uygulaması söz konusudur. ${ }^{54}$

En çok kayrılan ülke kuralı, ayrımcılık yapmama ilkesini belirlemekte ve bu kural, tarifelerin ve diğer uygulamaların ithal ve ihraç edilen mallar bakımından ülkeler arasında ayırımcılık yapılmaksızın uygulanmasını gerektirmektedir. Ancak, bu kuralın yukarıda da belirtildiği üzere bazı istisnaları da vardır. Tercihli veya gümrüksüz oranlara tâbi olan bölgesel ticaret düzenlemeleri üyeleri arasındaki (örneğin, $\mathrm{AB}$ üyesi devletlerarasındaki) ticaret, bu tür istisnalardan biridir. Diğer bir istisna ise Genelleştirilmiş Tercihler Sistemi olup, bu sistem uyarınca, gelişmiş ülkeler gelişmekte olan ülkeler menşeli malları gümrüksüz ithal etmekte veya bu ürünlere tercihli tarife uygulamakta, ancak diğer ülkeler menşeli ithal ürünlere en çok kayırılan ülke vergilerini uygulamaktadır.

Birkaç çekince ve başka adla da olsa "En Çok Kayırılan Ülke” ilkesi KAA'da bulunmaktadır. "En Çok Kayırılan Ülke” ilkesi, KAA'nın III.1(b) maddesinde 'milli muamele ve ayrımcılık yapmama ilkesi' olarak adlandırılan başlığı altında düzenlenmiş ancak açıkça bu ifadeye yer edilmemiştir. KAA'nın III.1(b) maddesi Anlaşmanın taraflarının, bazı taraf ülkelerin ürünleri, hizmetleri ve tedarikçilerine diğer taraf ülkelerin ürünlerine, hizmetlerine ve tedarikçilerine davrandıklarından daha olumsuz davranmamalarını gerektirmektedir.

\footnotetext{
${ }^{49}$ Kamu Alımları Anlaşmasının 3. maddesinin (1). fikrasının (a) bendi

${ }^{50}$ Kamu Alımları Anlaşmasının 3. maddesinin (1). fikrasının (b) bendi

${ }^{51}$ Kamu Alımları Anlaşmasının 3. maddesinin (2). fikrası

${ }^{52}$ Kamu Alımları Anlaşmasının özellikle 9, 18 ve 19. maddeleri

${ }^{53}$ T. Arat ve R. Erten, s.376.

${ }^{54}$ R. D. Anderson, (2007), s. 269.
} 
Bu çerçevede, "En Çok Kayırllan Ülke” ilkesi, KAA'ya taraf olan ülkelerin birbirlerinin ürünlerine ayırımcı muamelede bulunmasını önlemeye yönelik bir prensiptir. KAA bağlamında bu ilke ile GATT metninde yer alan "En Çok Kayırılan Ülke" ilkesinin benzerliği olsa da bazı yönlerden farklılığı vardır. Bu fark, KAA kapsamında kalan üye ülkelerin idare ve ürünlerine ilişkin kapsamın karşılıklılık ilkesine dayalı olmasıdır; yani, KAA tarafları uygulama kapsamına ilişkin olarak karşılıklı düzenlemelere bağlı olarak KAA'ya taraf ülkeler arasında farklı muameleler düzenleyebilirler. Örneğin, Avrupa Birliği KAA kapsamındaki yerel ve bölgesel kuruluşların düzenlediği kamu ihalelerine, KAA kurallarının bütün diğer KAA tarafi ülkelerin isteklileri açısından uygulanma imkânı varken, Kanadalı firmaların tekliflerine uygulanmaz.

KAA'ya taraf ülkelerin isteklileri arasında farklı muamelede bulunmama şeklinde uygulanan "En Çok Kayırılan Ülke" ilkesi KAA'ya taraf olmayan diğer DTÖ üyesi ülkelerin isteklileri açısından uygulanmaz. Örneğin, KAA’ya taraf bir ülke olan kapsamda kalan Japonya'daki idareler ihalelerinde KAA'ya taraf ülkeler olan İsviçre ve Singapur firmaları arasında ayırım yapmamalıdır. Ancak Japonya KAA'ya taraf ülkelerin isteklilerine DTÖ üyesi olup KAA'ya taraf olmayan diğer ülkelerin isteklilerinden daha elverişli koşulları uygulayabilir.

"En Çok Kayırllan Ülke” ilkesinin KAA bağlamındaki uygulamasının da sadece GATS kapsamında kalan hizmet alımları açısından geçerli olduğu, yoksa GATT kapsamındaki mal alımlarını konu alan kamu ihaleleri açısından geçerli olmadığı, bu ihalelere de GATT bağlamındaki "En Çok Kayırılan Ülke” ilkesinin uygulanacağı ileri sürülmüştür. GATS kapsamında kalan hizmet alımlarını konu alan kamu ihaleleri açısından KAA bağlamındaki "En Çok Kayırılan Ülke" ilkesinin uygulanacağı kesin iken GATT kapsamındaki mal alımlarını konu alan kamu ihaleleri açısından GATT bağlamındaki "En Çok Kayırılan Ülke” ilkesinin uygulanacağı tartışmalıdır. ${ }^{55} \mathrm{Bu}$ ayırımın da pratik açıdan sonucu, KAA'ya taraf bir ülkenin yaptığı GATT kapsamında kalan mal alımına ilişkin bir ihalede KAA'ya taraf ülkelerin isteklilerine KAA'ya taraf olmayan diğer DTÖ üyesi ülke isteklilerine göre daha elverişli koşulları uygulayıp uygulayamayacağıdır.

\section{Ayrımcılık yapma yasă̆ı kuralı}

Ayrımcılık yapma yasağı, Anlaşmaya taraf ülkelerin Anlaşma kapsamında kalan ihalelerde her türlü kanun, düzenleme, usul ve uygulamalar açısından yerli firmalar ile yabancı firmalar arasında ayırımcı muamelede bulunmamasinı temin etmektedir. GATT bağlamında ayrımcılık yapma yasağı, yabancı kişi ve firmalar açısından (ratione personae) ayrımcılık yapma yasağını ifade etmekte olup KAA bağlamında firma veya kişiler bazında bu yükümlülüğün yanı sıra KAA'da ürünler

\footnotetext{
${ }^{55}$ C. Bovis, (2006), "The New Public Procurement Regime: A Different Perspective on the Integration
} of Public Markets of the European Union”, European Public Law, 12 (1), ss. 73-109, s. 104. 
yönünden negatif bir listeleme ve hizmetler yönünden pozitif bir listeleme yapıldığı için konu bakımından da (ratione materiae) ayrımcı muamelede bulunulmasının önlenmesi durumu söz konusudur. ${ }^{56}$

\section{Milli (ulusal) muamele kuralt}

Milli (Ulusal) Muamele kuralı, yurt içinde uygulanan vergi ve muamelelerde yerli mal (hizmet) ve yabancı mal (hizmet) ayırımı yapılmaması ve hepsine eşit muamele yapılmasını sağlamaya yönelik bir kuraldır. En çok kayrılan ülke kuralının, değişik ülkeler menşeli mallar arasındaki ayırımcılı̆̆ı yasaklamasına karşılık ulusal işlem kuralı, iç vergilerin ve iç düzenlemelerin uygulanması çerçevesinde ithal edilen ürünler ile benzer yerel (ulusal) mallar arasında ayrımcılığı yasaklamaktadır. Ulusal Muamele ilkesine göre, DTÖ KAA'na taraf üyelerin ulusal (yerli) ve yabancı mallar, hizmetler ve yatırımlar arasında ayrım yapmamaları gerekmektedir. Ticaretteki bütün bu engellerin ve ayırımcılığın kaldırılması ile uluslararası ticarette serbestleşmenin (liberalleşmenin) sağlanması ve böylece bütün ülkelerin yararına olarak ticaret hacminin de artması hedeflenmektedir.

Ulusal muamele ilkesi, doğrudan KAA'na yazılmıştır. "Ulusal Muamele" ilkesine KAA'nın III.1(a) maddesinde yer verilmiştir. Buna göre, KAA'ya taraf bir ülke, KAA'ya taraf diğer ülkelerin firmaları ile ürünlerine ya da hizmetlerine kendi ulusal ürünleri ile hizmetleri ve tedarikçilere gösterilen muameleden daha olumsuz davranamaz. Ancak "Milli Muamele" prensibi Anlaşmaya taraf ülkelerin Ek-1'de ifade edilen idareler ve kapsamda kalan ihaleleri açısından uygulanacaktır. ${ }^{57} \mathrm{Bu}$ ilke gereğince, bir kamu ihalesi gerçekleştiren KAA'ya taraf bir ülkenin kapsam dâhilindeki bir kurumu, ihale üzerinde birakılan yüklenici tarafindan temin edilecek ürünlerin sadece kendi (kurumun bulunduğu) ülkesinden kaynaklanan ürünler olmasını talep edemez.

Ayrım gözetmeme ve ulusal muamele zamanda "offset uygulaması yasağını" 58

ilkesine uygun olarak, KAA aynı da içermektedir. KAA, anlaşma

\footnotetext{
${ }^{56}$ P. C. Mavrodis and B. M. Hoekman, (1995), "The WTO's Agreement on Government Procurement: expanding disciplines, declining membership?", Public Procurement Law Review, 2, ss. 63-79, s. 66.

${ }^{57}$ R. D. Anderson, (2006), "Current Developments on Public Procurement in the WTO", Public Procurement Law Review, 6, ss. NA167-178, s. NA168.

58“"Offset uygulamalarl”; kamu kurum ve kuruluşları ile kamu ortakları ve kamu iştirakleri tarafından yapılan ihalelerde çıkacak dövizi telafi etmek, ihracat potansiyelini, kendi ulusal sanayi ve üretim alanlarını geliştirmek, kendi kalifiye işgücünü oluşturmak, lisans ve know-how transferini gerçekleştirmek, ihale konusu iş alanındaki eğitimi artırmak amacıyla ihaleyi kazanan yabancı firmadan ihale sözleşmesine ek olarak alınan taahhütlerdir. Bu taahhütler ihalede yeterlik koşulu olarak öngörülebileceği gibi ihalenin karara bağlanması kriteri olarak da öngörülmesi mümkündür. KAA'nda "Offset uygulamalarl; ulusal unsurlar, teknoloji lisanslama, yatırım yapma zorunluluğu veya karşıllklı olarak yapılan ticarete iliş̧kin veya benzeri koşullar vasıtasıyla ulusal kalkınmayı
} 
kapsamında kalan idarelerin ihalelerinde ihale dokümanında, isteklilerin yeterliği ile tekliflerin değerlendirilmesi ve ihalenin karara bağlanmasına ilişkin olarak "offset uygulanmasına" yönelik işlem ve uygulama geliştirmelerini yasaklamaktadır. ${ }^{59}$ Bununla birlikte, gelişmekte olan ülkeler açısından, kalkınma ve genel politik argümanlar nedeniyle, KAA'na katılım aşamasında kendi ulusal telafi edici işlemlerin kullanımı, yani offset uygulamaları, konusunda müzakere yapabilir. Ancak bu tür koşullar ihalenin karara bağlanması kriteri olarak değil sadece isteklilerin ihaleye katılımı aşamasında bir yeterlik koşulu olarak öngörülebilir. Ayrıca bu koşulların açıkça tanımlanmış objektif ve ayrımcılık içermemesi gerekmektedir. Bunun yanı sıra böyle bir uygulamada bulunacak bir ülkenin bu durumunun Anlaşmanın ek-1 no'lu dokümanında belirtilmesi ve bu Anlaşmaya tâbi olan herhangi bir ihaledeki offset uygulamalarına ilişkin koşulların tam ve kesin olarak sınırlarının ortaya konulması gerekmektedir. Bunun yanı sira bu tür koşulların mevcudiyetinin DTÖ Kamu Alımları Komitesine bildirilmesi ve bu koşulları içerecek bir ihalenin ilanı ile ihale dokümanında bu hususa yer verilmesi gerekmektedir. ${ }^{60}$

\section{Şeffaflı ilkesi}

Şeffaflık ilkesi ile de üye devletler tarafindan Anlaşmalara uygun (DTÖ kapsamındaki Anlaşmaların konusuna giren) mevzuat içeren tüm yasa ve tüzüklerin yayımlanması gereği ile her bir üye ülkenin, diğer ülkelerin sektörlerinde yasa ve tüzüklere ilişkin bilgi edinebilecekleri bir bilgi iletişimi temin edilmektedir.

Yukarıda söz edildiği gibi KAA taraf devletleri, Kamu Alımları Komitesini kamu ihalesi mevzuatındaki değişiklikler hakkında bilgilendirmelidir. KAA'nın XIX. maddesi KAA taraf devletleri yıllık bazda KAA kapsamındaki kamu alımları hakkında istatistikler toplayıp bu Komiteye bildirmeleri gerekmektedir. Yukarıda söz edildiği gibi KAA taraf devletleri, Kamu Alımları Komitesini kamu ihalesi mevzuatındaki değişiklikler hakkında bilgilendirmelidir. KAA'nın XIX. maddesi KAA taraf devletlerini yıllık bazda KAA'nın kapsamındaki kamu alımları hakkında istatistikler toplayıp bu Komiteye bildirmelerini yükümlü kılıyor; ayrıca Taraf devletlerden biri, bir başka KAA tarafı devletin talebi üzerine Anlaşma kapsamındaki kuruluşların gerçekleştirdikleri kamu alımları ile bu kuruluşların

teşvik etmek veya ödemeler dengesi hesaplarını iyileştirmek için kullanılan önlemler” şeklinde tanımlanmıştır.

${ }^{59}$ J. H. Grier, s. 388. Ayrıca bkz.KAA md 16(1).

${ }^{60}$ KAA md 16(2). 
münferit olarak akdettikleri sözleşmeler hakkında bilgi vermek durumundadır (gizli bilgiyle ilgili GPA, XIX.4 maddesi hariç). ${ }^{61}$

Şeffaflık ilkesi KAA açısından yukarıdaki düzenlemenin yanı sıra kapsam dâhilinde kalan ihalelerin ilanı ile ihale sürecinin belli şeffaf kurallar altında işlemesini sağlama amacına da hizmet eder. Nitekim Kamu Alımları Anlaşmasının giriş kısmında şeffaflık ilkesine değinilmiş ve özel olarak da KAA'nın IX. maddesinde buna ilişkin bir düzenleme getirilmiştir.

KAA'nın IX. maddesine göre, idarelerin XV. maddedeki sınırlı ihale yöntemi hariç KAA kapsamında kalan ihaleler yönünden ihaleye katılımı sağlamak üzere bir ihale ilanı yayımlamaları öngörülmüştür. İhale ilanlarının bir özetinin de DTÖ'nün resmi dilleri olan İngilizce, Fransızca ve İspanyolca dillerinden birisi ile yayımı zorunluluğu vardır. KAA kapsamında kalan bir idarenin gene KAA kapsamında kalan bir ihale için yayımlayacağı ihale ilanında söz konusu ihalenin KAA kapsamında kaldığını belirtme zorunluluğu vardır. ${ }^{62}$ İhale ilanlarında şeffaflığı temin etmek üzere ihale usulünün belirtilmesi, ihale konusu işin miktarı ve işin yerine getirileceği yer ile süresi, ihaleye katılabilmek açısından isteklilerden istenen ekonomik ve mali koşullar ile teknik koşullar gibi hususlara yer verilmesi gerektiği ayrıntılı olarak ifade edilmiştir. ${ }^{63}$

KAA'da sonuç ilanı yayımlanması da öngörülmüştür. KAA kapsamında kalan ihalelerle ilgili $\mathrm{AB}$ kamu ihale yönergelerinde mevcut olan ön-ilan mevcut değildir. Ancak KAA'nın VII.(5) maddesinde merkezi hükümet kurumları dışındaki idareler açısından ön ilanın yapılmasına imkân getirilmiştir. Ayrıca, Taraf ülkeler, merkezi hükümet kurumları da dâhil olmak üzere KAA kapsamında kalan bütün idareler açısından ön ilan yapılması konusunda teşvik edilmiş ancak ön ilan yapılmasına yönelik zorunlu tutulmamışlardır. Ön ilan yapılması ilan süresinin kısaltılması açısından avantaj sağlayacaktır. ${ }^{64}$

Kamu Alımları Anlaşması'nda ilginçtir ki kamu ihalesi tanımı yapılmış değildir. Ancak Gümrük Tarifeleri ve Ticaret Genel Anlaşması (GATT) ile Hizmet Ticareti Genel Anlaşması (GATS) kamu alımlarını bu anlaşmaların belirli hükümlerinden hariç tutmak amacıyla bu konuda bir tanım içermektedirler. ${ }^{65}$

${ }^{61}$ KAA md XIX.4; "Herhangi bir Tarafa temin edilecek gizli bilgilerin, Kanunun yürürlüğ̈̈nü engelleyebilecek veya kamu yararına aykır olabilecek ya da kamu veya özel teşebbüslerin yasal ticari çıkarlarına zarar verebilecek veya tedarikçiler arasındaki adil rekabeti bozabilecek nitelikte olması halinde bilgiyi veren Taraftan resmi yetki almadan ifşa edilmeyecektir".

${ }^{62}$ P. C. Mavrodis and B. M. Hoekman, (1995), s.68.

${ }^{63}$ KAA md 9.

${ }^{64}$ R. D. Anderson, (2007), s. 261.

${ }^{65}$ Gümrük Tarifeleri ve Ticaret Genel Anlaşması (GATT) III: 8 (a) maddesi ve Hizmet Ticareti Genel Anlaşması (GATS) XIII: 1 maddesi. 
KAA'nın II.(2) maddesinde Anlaşmanın kapsamının belirlenmesi açısından kapsamda kalan kamu ihalelerine ilişkin bir tanım verilmiştir.

Şu hususu hatırda tutmakta fayda vardır ki, KAA sadece taraf ülkelerin kamu alımlarına özgü ticari engelleri kaldırmakla alakalıdır. Ancak malların ve hizmetlerin ticaretine yönelik gümrük vergileri, kotalar, ulusal teknik standartlardaki farklılıklar, hizmetlerin sunumuyla alakalı kişilerin serbest dolaşımı ile ilgili ulusal kısıtlamalar, mesleki eğitim ve diplomaların karşılıklı tanınmasına ilişkin eksiklikler gibi genel engeller aynı şekilde kamu alımlarına da uygulanmaktadır. KAA, serbest ticarete yönelik bu kısıtlamaların kaldırılmasını konu edinen bir Anlaşma olmayıp Anlaşma kapsamındaki malların ve hizmetlerin taraf ülkelerin kamu alımları piyasalarına girişini düzenleyen bir Anlaşmadır. Malların ve hizmetlerin serbest ticaretine yönelik yukarıda ifade edilen genel kısıtlamaların kaldırılmasını konu edinen Anlaşmalar ise GATT ve GATS Anlaşmalarıdır. Dolayısıyla, taraf ülkelerin KAA kapsamındaki taahhütleri aynı zamanda malların ve hizmetlerin serbest ticaretini üye ülkelerin genel olarak piyasalarına girişini düzenleyen GATT ve GATS Anlaşmaları bağlamındaki kural ve kısıtlamalara da tâbidir. Örneğin, İsviçreli bir istekli İsviçre menşeli bir ürünü KAA kapsamında kalan bir ürününü Avusturya'daki bir kamu ihalesinde teklif edecek olursa bu ürüne ilişkin GATT uyarınca ödenmesi gereken Avusturya'nın ithal için istediği ilgili gümrük vergilerini vermek durumundadır. ${ }^{66}$

Kamu Alımları Anlaşmasının 3. maddesi yukarıda bahsedilen "milli muamele ilkesi" ve "en çok kayırılan ülke prensibi" ile "ayrımcıllk yasağını" düzenlemektedir. Madde metni aşağıda sunulmuştur. Bu madde ile yerli istekliler ile yerli ürün ve hizmetlere ilişkin kamu ihalesi mevzuatı ile uygulamalarının KAA'ya taraf olan ülkeler menşeli ürün ve hizmetler ile isteklilere de aynı şekilde uygulanmasını öngörmektedir.

$\mathrm{Bu}$ prensipler Hizmet Ticareti Genel Anlaşmasında (GATS) yer alan "ulusal muamele" ile "en çok kayırılan ülke prensibi" ile örtüşmekte ve genel olarak ayırımcı muamele yasaklanmaktadır. Ayrıca KAA'na göre, taraf ülkelerden Anlaşma dâhilindeki kamu alımları ile ilgili her türlü kanun, düzenleme, usul ve uygulamalar açısından yerel olarak kurulmuş bir tedarikçiye, yabancı bağlantıları veya firmadaki sahiplik oranı nedeniyle yerel olarak kurulmuş diğer bir tedarikçiden daha az avantajlı muamelede bulunulmamasını temin etmesi istenmiştir. Ayrıca yerel olarak kurulmuş tedarikçilere malın üretildiği veya hizmetin sağlandığı ülke bazında ayrımcı bir şekilde davranılmamasını temin etmeleri istenmiştir. ${ }^{67}$

\footnotetext{
${ }^{66} \mathrm{M}$. Dischendorfer, ss. 21-22.

${ }^{67} \mathrm{KAA}$ md 3(2).
} 
Kamu Alımları Anlaşmasının III. maddesi özetle, bu şekilde en çok kayırılan ülke prensibi ve yabancı hizmetler ile yabancı tedarikçiler açısından ayrımcı olmama hususunda diğer taraflara eşit muamele edilmesini düzenlemiş bulunmaktadır. Arrowsmith, KAA'nın Uruguay Turu görüşmelerinde bu Anlaşmaya taraf ülkelerin en çok kayırılan ülke prensibini uygulamaktan imtina etmelerine imkân vermesi ve üye ülkelerin de bu prensibe ilişkin derogasyonu çok kullanmaları nedeniyle KAA'nın çok taraflı bir anlaşmadan çok bir dizi iki taraflı anlaşmalar mahiyetinde olduğunu belirtmiştir. ${ }^{68}$

\subsection{Az Gelişmiş ve Gelişmekte olan Ülkeler için Özel ve Ayrı Muamele}

KAA'ya taraf devletler, bu Anlaşmanın uygulanması ve gereklerinin yerine getirilmesi esnasında KAA'nın V. maddesi hükümlerini uygulayarak, kalkınmakta olan ülkelerin, özellikle de az gelişmiş ülkelerin kalkınma, mali ve ticari gereksinimlerini dikkate alacakları belirtilmiştir. Bu ülkelerin KAA'ya taraf olmalarını sağlamak için yapılacak müzakerelerde bu ülkelerin ödemeler dengesi konumlarını korumak; ulusal endüstrilerinin kurulmasını veya gelişimini desteklemek; kamu alımına bağlı olan endüstriyel birimleri desteklemek ve bölgesel veya uluslararası düzenlemeler çerçevesinde ekonomik kalkınmayı teşvik etme durumlarının dikkate alınması gerekmektedir. Ancak bu kural gelişmekte olan ve az gelişmiş ülkelerin ihtiyacıyla ilgili olarak sinırlıdır.

KAA'nın V.2 maddesine göre, kamu alımlarıyla ilgili düzenlemelerin hazırlanması ve uygulanmasında KAA'ya taraf gelişmiş ülkeler, az gelişmiş ülkelerden daha fazla ithalat yapılmasını kolaylaştırmalı ve bu arada az gelişmiş ülkelerin ve ekonomik kalkınmanın alt aşamalarındaki ülkelerin özel sorunlarına dikkat etmelidir. ${ }^{69}$ KAA'nın V.2 maddesindeki bu kural, gelişmiş bir ülkedeki bir kamu kurumunun gerçekleştirdiği bir ihalede gelişmekte olan bir ülke firmasının teklifi lehine olup gelişmiş bir ülke firmasının aleyhine bir uygulama yapılmasını gerektirmez. Bu kural, sadece gelişmekte olan ve az gelişmiş ülkelerden yapılacak ithalatın kolaylaştırılmasını gerektirmektedir.

KAA'nın V.4 maddesi uyarınca, gelişmekte olan bir ülke KAA'nın kapsama ilişkin eklerinde yazılı olan belli kurumlar, ürünler ve hizmetlerle ilgili olarak "Ulusal Muamele" ilkesiyle ilgili istisnaları müzakere edebileceğini belirtmektedir. ${ }^{70} \mathrm{Bu}$ istisna, KAA'nın gelişmiş ülkeleriyle karş1lıklı bir anlaşmaya bağlıdır. KAA'nın V.5 maddesi, gelişmekte olan ve az gelişmiş ülkeler açısından

\footnotetext{
${ }^{68}$ S. Arrowsmith, (2003), Government Procurement in the WTO, Studies in Transnational Economic Law, Kluwer Law International, The Hague, s. 111.

${ }^{69} \mathrm{KAA}$ md V.2.

${ }^{70}$ KAA md V.4; "Gelişmekte olan bir ülke bu anlaşma dâhilindeki müzakereler strasında her bir durumun kendine özgü koşullarını dikkate alarak, kapsam listesinde bulunan belirli kuruluşlar, mallar veya hizmetlerle ilgili olarak milli (ulusal) muamele kuralları açısından karşılıklı mutabakat yoluyla istisnaları diğer katılımcılarla müzakere edebilir."
} 
KAA yürürlüğe girdikten sonra da KAA kapsamındaki kurumların ve ürünlerin kapsamını değiştirmelerine izin vermektedir.

KAA'nın XVI.2 maddesi uyarınca; gelişmekte olan bir ülke, kalkınmayla ilgili unsurlar dâhil olmak üzere genel politik unsurları da dikkate alarak, KAA'ya katılım sırasında ulusal bazı unsurların dâhil edilme koşulları gibi offset'lerin kullanımı (örneğin, ulusal sanayi ve ulusal üretim alanlarını geliştirme, kendi kalifiye işgücünü oluşturma veya know-how transferini gerçekleştirme) konusunda müzakere yapabilir. Ancak bu tür koşullara ihalenin karara bağlanması kriteri olarak değil sadece ihaleye katılımda bir yeterlik koşulu olarak yer verilebilecektir. Ayrıca bu koşulların objektif ve açıkça tanımlanmış olması ve uygulanmasında ayrımcılık yapılmaması gerekmektedir. Bu koşulların o ülkenin 1 no'lu ilavesinde belirtilmesi ve bu Anlaşmaya tâbi olan herhangi bir ihalede offset uygulamasına ilişkin sınırların da tam ve kesin olarak belirtilmesi gerekmektedir. Bu tür koşulların varlığının Kamu İhale Komitesine bildirilmesi ve öngörülen ihaleye ilişkin ilan ile diğer ihale dokümanında belirtilmesi gerekmektedir.

KAA gelişmekte olan ve az gelişmiş ülkeler için uygun olmamakla eleştirilmiştir. Nitekim gelişmekte olan ve az gelişmiş ülkeler için KAA'nın V. maddesinde getirilen düzenleme bu ülkelerin ilgisini çekmemiştir. ${ }^{72}$ Gelişmekte olan ve az gelişmiş ülkeler için aşağıda incelenecek olan özel ve ayrı muamele kurallarının bazı müphem unsurları vardır. En başında belirtmek gerekir ki, DTÖ mevzuatı çerçevesinde gelişmekte olan ve az gelişmiş ülkelerle ilgili bir tanım yoktur. Bu belirsizlik nedeniyle de bir KAA tarafı ülkenin, kendini gelişmekte olan veya az gelişmiş bir ülke olarak sınıflandırması ve tanımlaması ancak diğer KAA tarafı üye ülkelerle bu konuda yapılacak müzakere sonucunda mümkün gözükmektedir. Gelişmekte olan ve az gelişmiş ülkeler açısından, aşağıda değinilecek olan istisna ve offset uygulamaları elde etme açısından bu ülkeler gerekli müzakere gücüne sahip olmayabilirler. Ayrıca KAA'nın V. maddesi metni çok müphem olup bu belirsizlik de anlaşmazlıklara yol açabilir.

KAA V. maddesinde, gelişmekte olan ve az gelişmiş ülkelerin KAA'na taraf olmalarını teşvik edici geçiş önlemleri daha açık bir şekilde ifade edilmiştir. Bu ülkelere belli bir geçiş süresi içerisinde fiyat avantajı, offset uygulamaları, belli

${ }^{71}$ KAA md V.5; “Bu Anlaşmanın yürürlüğe girmesinden sonra, gelişmekte olan KAA'ya Taraf bir ülke, kalkınma, mali ve ticari ihtiyaçlarını dikkate alarak XXIV. maddenin 6. fikrasında belirtilen bu tür kapsam listelerinin değişikliği ile ilgili hükümlere uygun şekilde kapsam listelerini değiştirebilir veya her bir vakanın kendine özgü koşulları ile 1. fikranın (a) ila (c) bentlerinin hükümlerini gereklerini dikkate alarak, Kamu Alımları Komitesinden, kendi listesinde bulunan belli kuruluşları, malları veya hizmetleri milli (ulusal) muamele kuralları dışında tutmasını talep edebilir".

${ }^{72}$ V. G. De Lima de Silva, (2008), "The revision of the WTO Agreement on Government Procurement: to what extent might it contribute to the expansion of current membership?", Public Procurement Law Review, ss. 61-98. 
sektör ve kuruluşların aşamalı olarak Anlaşmaya dâhil edilmesi, eşik değerlerin geçiş süresi içerisinde ülkelerin bulunduğu kalıcı eşik değer düzeyine göre daha yüksek tutulması gibi uygulamalar ile özel ve farklı muamelede bulunma imkânı tanınmıştır. Bu ülkelerin, diğer Anlaşmaya taraf ülkelerin ürünleri, hizmetleri ile tedarikçilerine eşit muamelede bulunma yükümlülüğü dışında Anlaşma kapsamındaki herhangi bir yükümlülüğün yerine getirilmesini belli bir süre erteleyebilmelerine imkân tanımaktadır. Az gelişmiş ülkeler için bu geçiş süresi; Anlaşmaya katılımından itibaren beş yıl olup, gelişmekte olan ülkeler açısından da her halükarda üç yılı aşmayacak ve belli bir yükümlülüğün yerine getirilebilmesini sağlayacak uzunluktaki bir süredir. Bu süreler Kamu Alımları Komitesi tarafından ilgili ülkenin talebi üzerine uzatılabilir. Kamu Alımları Komitesinin bu hükmün uygulanması ve etkililiği konusunu beş yılda bir değerlendirmesi öngörülmüştür.

\section{Sonuç}

Önceki KAA'ya taraf olan ülkelerin sayısı DTÖ çerçevesinde diğer Anlaşmalara (GATS; TRIPS v.s) taraf olan ülkelere oranla düşük sayıda olması bu Anlaşmanın içeriği ile bağlayıcılığı konusunda yenilenmelere ihtiyaç olduğunun en açık kanıtıydı. Özellikle bu Anlaşmaya taraf olmakta çekimser davranan az gelişmiş ve gelişmekte olan ülkelerin kamu alımları piyasalarını açmakta duydukları endişelerinin telafisi gerekmekteydi. KAA, taraf devletler açısından bağlayıcıdır ve gerçek ve tüzel kişiler ulusal merciler nezdinde KAA'nın uygulanmasını ileri sürebilirler. Ancak KAA'nın önceki metni her zaman anlaşılır değildi. KAA taraf devletleri, önceki KAA'dan hem metin hem de yapı açısından daha anlaşılır olan yeni KAA metninin 2014 yılı içerisinde eski Anlaşmaya taraf ülkelerin üçte ikisi tarafından kabul edilmesi sonucunda 6 Nisan 2014 tarihinde yürürlüğe girmiştir.

DTÖ’nün yeni Kamu Alımları Anlaşması denebilir ki çok yakın bir süreçte olmasa bile gelecekte kamu ihale piyasalarının dünya ölçeğinde liberalleşmesinin ana çerçevesi olacaktır. Nitekim, Türkiye'nin de aktif olarak katılım gösterdiği 18 Aralık 1996 tarih ve WT/MIN (96) simgeli DTÖ belgesi olarak yayımlanan Singapur Bakanlar Deklarasyonu'nun 21'inci maddesi uyarınca oluşturulan "Kamu Alımlarında Şeffaflık Çalışma Grubu” bu alanda önemli çalışmalar yaparak kamu ihale piyasalarında genel olarak şeffaflığı sağlamada global düzeyde önemli bir bilinçlenme ortamı yaratmış ve ileride henüz Kamu Alımları Anlaşmasına taraf olmayan DTÖ üyeleri için önemli bir basamak olmuştur. DTÖ KAA, uluslararası kamu ihale piyasalarına girişi kolaylaştıran bir kurallar manzumesi olmasının yanı sıra iyi yönetişim hedefi yönünden de önemli bir katkı sağlamaktadır. İhale mevzuatını tatbik etmekle görevli kişilerin de bu konuda bilinçlendirilmeleri ve söz konusu kuralların tam ve etkin bir şekilde uygulanmasını sağlamaya yönelik tedbirlerin alınması gerekmektedir. 
DTÖ Kamu Alımları Anlaşması hem AB üyesi devletler hem de AB tarafından birlikte imzalanan bir anlaşmadır. DTÖ Kamu Alımları Anlaşması AB hukukunun bir parçası olduğundan $\mathrm{AB}$ üyesi ülkelerin ulusal mahkemeleri KAA'nın yorumu konusunda ABAD'a başvuru olanağına sahiptirler. ABAD ABİHA'nın 267. maddesinin birinci paragrafı bağlamında KAA hükümlerinin yorumu konusunda ön karar davası yöntemiyle karar vermeye de yetkilidir. Uluslararası hukuka göre Taraf ülkelerin KAA hükümlerine kendi İç Hukuklarında doğrudan etki tanıması her bir Taraf ülkenin kendisine kalmış bir konudur. Bu açıdan bakıldığında Avrupa Birliği'nin de diğer KAA Tarafı ülkeler karşısında KAA hükümlerine doğrudan etki tanıma zorunluluğu bulunmamaktadır. 


\section{Kaynakça:}

Adaoğlu H., (2006), AT Hukukunun Üye Ülkelerde Uygulanmasında Ulusal Mahkemeler ve ATAD İlişkisi, Ankara Üniversitesi Avrupa Toplulukları Araştırma ve Uygulama Merkezi Araştırma Dizisi No: 24, Ankara Üniversitesi Basımevi, Ankara.

Agreement on Government Procurement, http:/www.wto.org/english/docs_e/legal_e/gpr94_e.pdf, Erişim: 15 Ocak 2014.

Anderson R. D., Muller A.C., Osei-Lah K. \& Pelletier P., (2012), “Assessing the value of future accessions to the WTO Agreement on Government Procurement: some new data sources, provisional estimates, and an evaluative framework for WTO members considering accession", Public Procurement Law Review, 4, ss. 113-138.

Anderson R. D. \& Kovacic W. E., (2009), "Competition policy and international trade liberalisation: essential complements to ensure good performance in public procurement markets", Public Procurement Law Review, 18(2) ss.67-101.

Anderson R. D., (2007), "Renewing The WTO Agreement On Government Procurement: Progress To Date And Ongoing Negotiations", Public Procurement Law Review, 4, ss. 255-273.

Anderson R. D., (2006), "Current Developments on Public Procurement in the WTO", Public Procurement Law Review, 6, ss. 167-178.

Anderson R. D., (2012), "The conclusion of the renegotiation of the World Trade Organization Agreement on Government Procurement: what it means for the Agreement and for the world economy", Public Procurement Law Review, 3, ss. 83-94.

Arat T. ve Erten R., (2008), “DTÖ Hukuku ve Türkiye'ye Etkileri”,in M. Sait Akman ve Şahin Yaman (Ed.),Dünya Ticaret Örgütü Doha Turu Çok taraflı Ticaret Müzakereleri ve Türkiye, Ankara, Tepav Yayınları No:39.

Arrowsmith S., (2003), Government Procurement in the WTO, Studies in Transnational Economic Law, Kluwer Law International, The Hague.

Arrowsmith S., (1996), The Law of Public and Utilities Procurement, Sweet \& Maxwell, 1st Edition, London.

Arrowsmith S. Linarelli J.\& Wallace D., (2000), Regulating Public Procurement, Kluwer Law International, London, 1st Edition.

Bovis C., (2006), "The New Public Procurement Regime: A Different Perspective on the Integration of Public Markets of the European Union”, European Public Law,12(1), ss. 73-109.

Cao F. (2013), "Building up SME programmes in government procurement in China: legal structure, recent developments and the way forward towards the WTO-GPA", Public Procurement Law Review, 6, ss. 211-224. 
Cao F., (2006), "Developments in China: the regulations implementing the Chinese Government Procurement Law, and progress towards GPA accession", Public Procurement Law Review, No. 6, ss. 205-213.

Dahlgaard D. D., (1999), A Harmonization of the National Judicial Review of the Application of European Community Law, Kluwer Law International, The HagueLondon-Boston.

De Lima de Silva V. G., (2008), "The revision of the WTO Agreement on Government Procurement: to what extent might it contribute to the expansion of current membership?", Public Procurement Law Review, 17(2), ss. 61-98.

Dischendorfer M., (2000), "The existence and development of multilateral rules on government procurement under the framework of the WTO", Public Procurement Law Review, 1, ss. 1-38.

Dünya Ticaret Örgütü, (2008), World Trade Report 2008: Trade in a Globalising World, http://www.wto.org/english/res_e/booksp_e/anrep_e/world_trade_report08_e.pdf, Erişim: 18 Kasım 2013.

Grier J. H., (2006), "Recent Developments In International Trade Agreements Covering Government Procurement”, Public Contract Law Journal, 35(3), ss. 385-407.

Hoekman B. M. \& Mavrodis P. C., (1997), "Law and Policy in Public Purchasing: The WTO Agreement on Government Procurement", Hoekman B. M. \& Mavrodis P. C. (Ed.), Multilateralizing the Agreement on Government Procurement, Studies in International Trade Policy, Ann Arbor: University of Michigan Press, ss. 289-312.

Kaczorowska A., (2013),European Union Law,Published by Routledge-Cavendish, Abingdon, Oxon, 3rd Edition.

Mavrodis P. C. \& Hoekman B. M., (1995), "The WTO's Agreement on Government Procurement:expanding disciplines, declining membership?", Public Procurement Law Review,4, ss. 63-79.

Mccrudden C. \& Cross S. G., (2006), "WTO government procurement rules and the local dynamics of procurement policies: a Malaysian case study", European Journal of International Law, 17(1), ss. 151-185.

Parties, observers and accessions, http://www.wto.org/english/tratop_e/gproc_e/memobs_e.htm\#parties, Erişim: 15 Ocak 2014.

Ping W., (2012), "The renewed momentum for the expansion of the WTO Agreement on Government Procurement", Public Procurement Law Review, 4, ss. 157-159.

Pre-WTO legal texts,http://www.wto.org/english/docs_e/legal_e/prewto_legal_e.htm, Erişim: 15 Ocak 2014.

Roebling, G., (1999), "Invoking the Agreement on Government Procurement", Public Procurement Law Review, 4, ss. 187-208. 
United Nations Commission on International Trade Law, http://www.uncitral.org, Erişim: 10 Ocak 2014.

Van Den Bossche P., (2005), The Law and Policy of the World Trade Organization-Text, Cases and Materials, Cambridge: University Press.

WTO, What is the GPA, http://www.wto.org/english/tratop_e/gproc_e/gp_gpa_e.htm, Erişim: 15 Ağustos 2014. 